Portland State University

PDXScholar

$6-21-2021$

\title{
Opportunities for Vietnam's Footwear Industry After the 2019-2020 Pandemic to Achieve Competitive Advantage
}

Thuan Nguyen

Portland State University

Follow this and additional works at: https://pdxscholar.library.pdx.edu/honorstheses

Part of the Operations and Supply Chain Management Commons

Let us know how access to this document benefits you.

\section{Recommended Citation}

Nguyen, Thuan, "Opportunities for Vietnam's Footwear Industry After the 2019-2020 Pandemic to Achieve Competitive Advantage" (2021). University Honors Theses. Paper 1079.

https://doi.org/10.15760/honors.1106

This Thesis is brought to you for free and open access. It has been accepted for inclusion in University Honors Theses by an authorized administrator of PDXScholar. Please contact us if we can make this document more accessible: pdxscholar@pdx.edu. 
Opportunities for Vietnam's Footwear Industry After the 2019-2020 Pandemic to Achieve Competitive Advantage.

by

\section{Thuan Nguyen}

An undergraduate honors thesis submitted in partial fulfillment of the requirements for the degree of

Bachelor of Arts

in

University Honors

and

Supply chain and Logistic

Advisor: Dr. Carlos Mena

Portland State University 
Table of contents

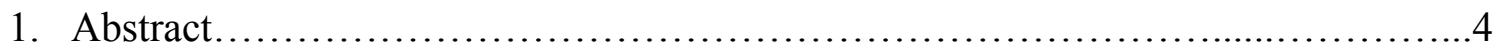

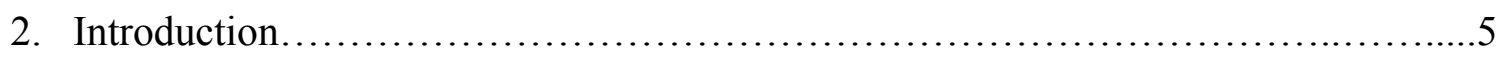

a. Problem discussion...............................................6

b. Research question.............................................6

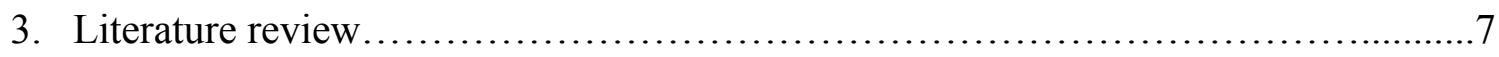

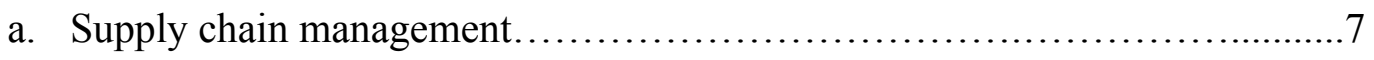

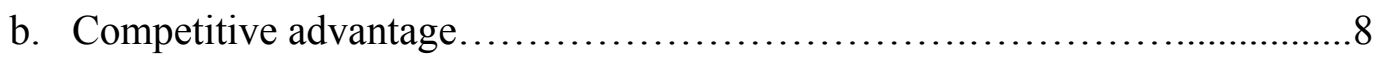

4. Theory: Porter Diamond Model...............................................11

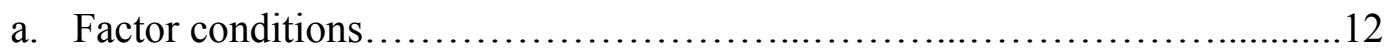

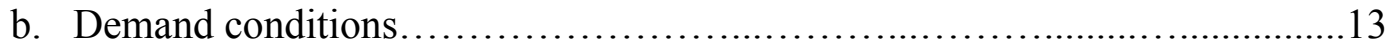

c. Related and supporting industries..........................................13

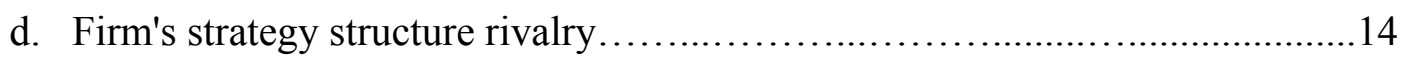

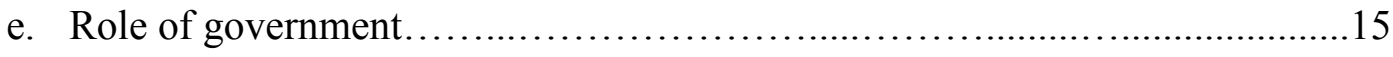

f. Chance..................................................................... 15

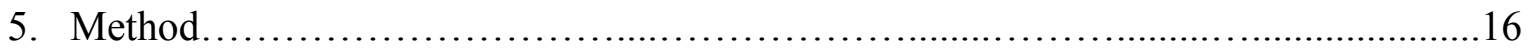

a. Methodological approach.................................................. 16

b. Methodological strategy: Quantitative and qualitative................................18

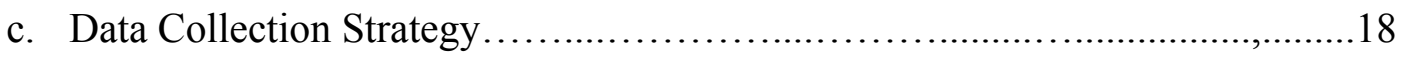

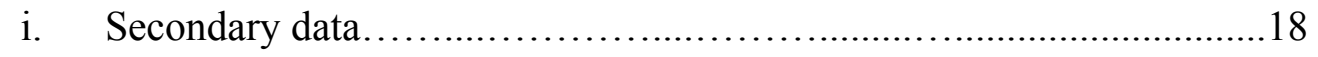

ii. Primary data................................................................ 18

d. Limits of the study.............................................................. 19

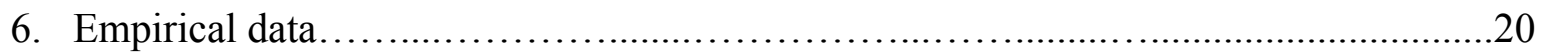




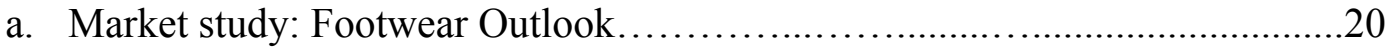

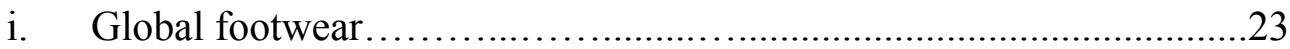

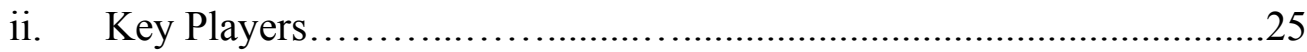

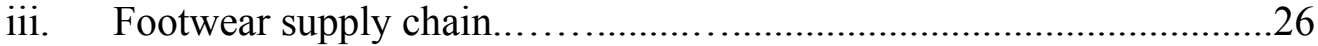

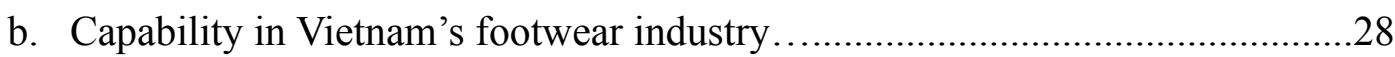

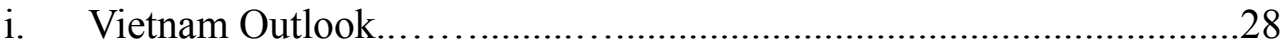

1. Economic..................................................................29

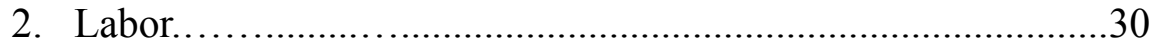

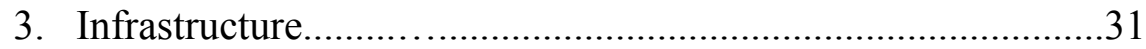

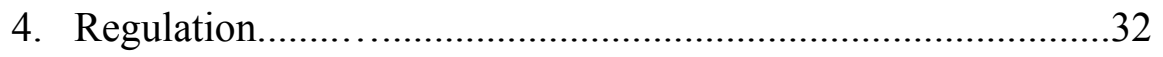

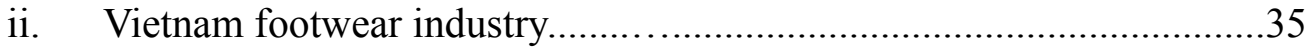

1. Vietnam footwear manufacture.............................................35

2. Domestic footwear market....................................................36

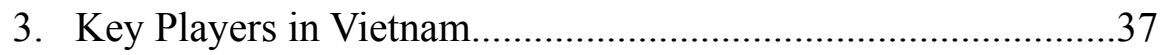

iii. Effect of the pandemic of 2019-2020 on Vietnam...............................40

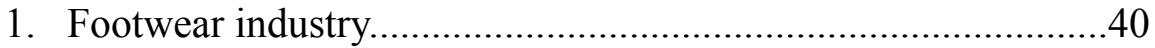

2. Vietnam and its footwear industry.....................................42

7. Results/discussion: Applying Porter's Diamond Model.............................................43

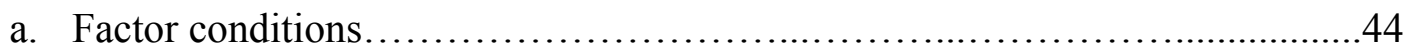

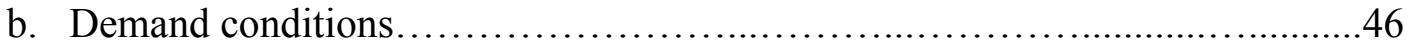

c. Related and supporting industries.............................................4

d. Firm's strategy structure rivalry.............................................48

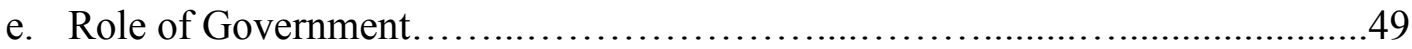


Nguyen 3

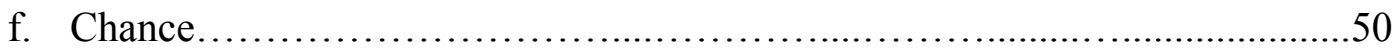

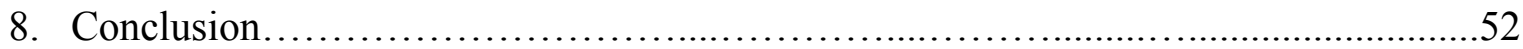

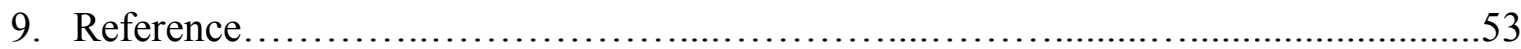




\begin{abstract}
:
Vietnam's footwear industry is the main topic of the research. The thesis paper will evaluate the industry's current performance based on existing data to discover Vietnam's footwear opportunities to achieve a competitive advantage over other countries after the COVID-19 pandemic. Vietnam plays a crucial role in the global footwear industry and its supply chain. My thesis methodology will be an abductive approach strategy, using both data and theory to find an explanation, which itself can be shown to be true or viable. The research and implementation theory of Michael Porter's Diamond Model will allow for the identification of opportunities for the industry to achieve competitive advantage in smaller factors. To answer the research question, I will gain a deeper understanding of the competitive advantage Vietnam footwear already has, the current trend on this market, and the foreign customer's perception. Vietnam's footwear industry needs innovative automation technologies to increase production, sophisticated domestic buyers, investment in domestic enterprises, diversified relationships with supporting industries, show commitment to social responsibilities, and improving workers' skills as a way to overcome difficulties and gain access to resources that contribute to the nation's competitive advantage. It is necessary to focus on the future to achieve the desired performance of the supply chain in terms of service level and logistic costs, creating the nation's economic growth.
\end{abstract}

Keywords: Footwear, supply chain, competitive advantage, COVID-19 pandemic 


\section{Introduction:}

The devastating effects of the pandemic have led to a near-total disruption of the world's social fabric. Additionally, global economics has been all but paralyzed and filled with many uncertainties. A pandemic that lasts longer than a year will lead to many business failures and mass unemployment — throwing the world into a global recession. The virus caused shocks on the supplies side due to higher levels of absenteeism based on much greater reliance on manufacturers around the world (focusing on Chinese-made supply chain components). If the virus remains in an affected country and disrupts its global production lines, the increased risk profile in doing business will lower foreign investment and export activities in that country. Normal business operations are significantly affected as percentages of workers get sick, become scared to go to work, or cannot return to work because of public health measures (International Labour Organization, 2020). As the effects of the pandemic are not likely to disappear in the near future, proactive international actions are required to save lives as well as protect and improve economic prosperity.

\section{Problem discussion:}

The COVID-19 pandemic has negatively impacted all retail sectors, and the footwear category is no exception (DeSalva, 2020). This paper investigates opportunities in Vietnam's footwear industry after the $2019-2020$ pandemic. This paper will help distributors to answer the questions regarding how the footwear exportation between Vietnam and the global footwear industry has been affected by the pandemic of 2019-2020 and what specific opportunities and challenges Vietnam is facing.

This study aims to innovate the global supply chain and build resilience for the Vietnamese economy through the use of literature reviews, experts' reports, and applications of 
financial and non-financial performance measurement tools. With Vietnam's footwear industry as the main topic of the research, my work will evaluate the country's current supply chain performance based on the existing framework. Furthermore, the study will evaluate the issue using insight from leaders in the footwear manufacturers such as Nike and Adidas. Ultimately, the results of my analysis will add value to the study of how Vietnam's footwear industry can achieve competitive advantages over other countries after the pandemic of 2019-2020.

\section{Research question:}

What are the opportunities for Vietnam's footwear industry to achieve a competitive advantage over other nations after the 2019-2020 COVID-19 Pandemic? 


\section{Literature Review:}

\section{What is supply chain management?}

The paper will be focusing on the supply chain of the footwear industry. It is crucial to define the process of a supply chain first: "a supply chain deals with the conversion of raw materials into finished goods and timely delivery of the products to end-users, and backward" (Mabert and Venkataramanan, 2007, p. 4). There are many different functions of the supply chain that make it extremely significant in every part of the transaction of goods/services when being bought and sold. The ultimate goal of the supply chain is to create a process of getting goods or services in the most convenient and effective manner. Therefore, supply chains fit into every business in many forms and have an essential role in their success. Supply chain management (SCM) focuses on providing the right customers with the right items at the right price, in the right volume at the right place, at the right time, and in the right condition (Naoui, 2014). The supply chain includes all activities associated with the flow and transportation of goods from the raw material stage to end-users and the related information flow.

SCM's goal is to have goods available when the consumer demands them, aiming to maximize the overall value generated. SCM involves data collection of organization then analysis and interpretation. Such information helps to paint a clear picture of the fundamental structure of the supply chain as well as the key contacts, suppliers, and stakeholders along the supply chain specific to each company. As supply chains are becoming more complex and the world is growing at an unimaginable rate, concerns are increasing about low-probability/ high-impact events that can bring about significant earnings, shortfalls, or unplanned exits from the business (Sheffi, Y. 2005). SCM is critical as companies seek to strengthen operations and business resilience by forecasting, preparing, and reducing potential risks (McKenzie, 2020). To 
develop an appropriate strategy, SCM is required to understand the variety of demands from the supply chain and foresee potentially conflicting tensions to be managed. According to Baker McKenzie (2020), there is rapidly increasing importance placed on supply chain management; expertise in the field is expected to add value in many levels, from operational teams to the boardroom. Companies that learn how to build and participate in solid supply chains will have a substantial competitive advantage in their markets.

Competitive advantage: Michael Porter.

In every competitive situation, the winners are generally those with the better strategy. Frank Rothaermel wrote in his book, Strategic management, "A firm that formulates and implements a strategy that leads to superior performance relative to other competitors in the same industry or the industry average will achieve a competitive advantage" (2009, p. 4-7). A competitive advantage is defined as a factor that grants to one producer goods or services of better quality or lower price than those of its rivals. While the term is commonly used for businesses, the strategies work for any organization, country, or individual in a competitive environment. The concept was first introduced in 1980, by Harvard Business School Professor, Michael Porter in his book Competitive Strategy. Five years later, Porter wrote the Competitive Advantage, the definitive business school textbook on the topic which helps companies to create a sustainable competitive advantage. Advertising products or services with lower prices and higher quality interests consumers. Target markets must recognize these unique products or services. This is the reason behind brand loyalty, why customers prefer a particular product or service.

Porter also wrote a book called The competitive advantage of nations in which he elevates the concept of competitive advantage to a national level. The concept of competitive 
advantage national level was first introduced by Porter (1990) as a tool of analysis in increasing the competitiveness of a country in a given industry. The book changed the focus on answering the bigger questions of why certain nations are more competitive than others in a certain industry and how one measures and defines competitive advantage on the country level. Every nation has different values that could contribute to its competitive success, including culture, economic structures, institutions, and histories. Porter (1990) argues a nation's competitiveness depends on the capacity of its industry to innovate and improve. The book introduces Porter's Diamond Theory of National Advantage, "a whole new way to understand the competitive position of a nation (or other locations) in global competition that is now an integral part of international business thinking” (Porter,1990,p.77). Understanding the source of a national competitive advantage can help identify strategies for the country to grow and innovate. The more sustainable the competitive advantage, the more troublesome it is for others to overtake. Porter's Diamond Theory states that there are four determinants factors of national competitive advantage:

- Factor conditions

- Demand conditions

- Related and supporting industries

- Firm's strategy structure rivalry

Two other less influential factors that will help influence the four factors are the role of government and chance. They support and complement the system of national competitiveness but do not create long-lasting competitive advantages.

Furthermore, many writers have expanded on Porter's ideas, acknowledging that a country's competitiveness can be seen from its capacity to trade products and services. 
Altomonte, Aquilante, and Ottaviano (2012) show that volume exports of a focus industry can measure a country's competitiveness. They claim that competitiveness is gained by expanding the capacity to trade the products and services readily available in the home nation for goods and services from another country that are rare in the home nation (Altomonte, Aquilante, and Ottaviano, 2012). For a country to remain successful and sustain economic growth, it will need export activities and domestic demand (Tsen, 2010). This idea implies that a country with cost advantages in its products will specialize and export those products, and will import products with the smallest absolute advantages (Smit, 2010). Porter (1990) points out that entrepreneurs and organizations must take advantage of certain regions' comparative advantage to gain competitiveness in their industry. 


\section{Theory: Porter's Diamond Model}

Michael Porter's Diamond Model (also known as the Theory of National Competitive Advantage of Industries) (\#Figure1) is used by organizations to analyze the external competitive environment, explaining the relative strengths of one business against another, and why some industries are more advantageous than others in a particular region. Porter (1990) defines the competitive advantage of a nation as its capacity to entice firms (both local and foreign) to use the country as a platform from which to conduct business. He introduced what has become known as the 'National Competitive Advantage of Industries' with four factors' determining the competitive strengths and weaknesses of countries and their major sectors. The model attempts to answer the questions of finding the opportunities for Vietnam's Footwear industry after the 2019-2020 Pandemic to achieve competitive advantages. In many developing countries, the 'diamond' model can help create policy makers see opportunities to increase competitiveness and focus on building industries and thereby improve national performance. Porter identifies four factors of a country's attributes as factor conditions: demand conditions, related and supported industries, and company strategy, structure, and rivalry. He also proposes two other nominal factors within the model which are, the role of Government and chance. Government support and intervention help innovate the industry or at times create disadvantages. Chance factors such as wars, significant shifts in world financial markets, discontinuities in input costs (e.g. oil price shocks), or major technological breakthroughs can have a significant impact on a nation's competitive advantage. They are there to act as a catalyst and challenger over other four factors; it is to encourage, or even to push the country to enhance their performance to gain a competitive advantage, leading to creating change in the industry. Therefore, nations can influence competitive advantage by systematically improving each of the elements of the diamond. 


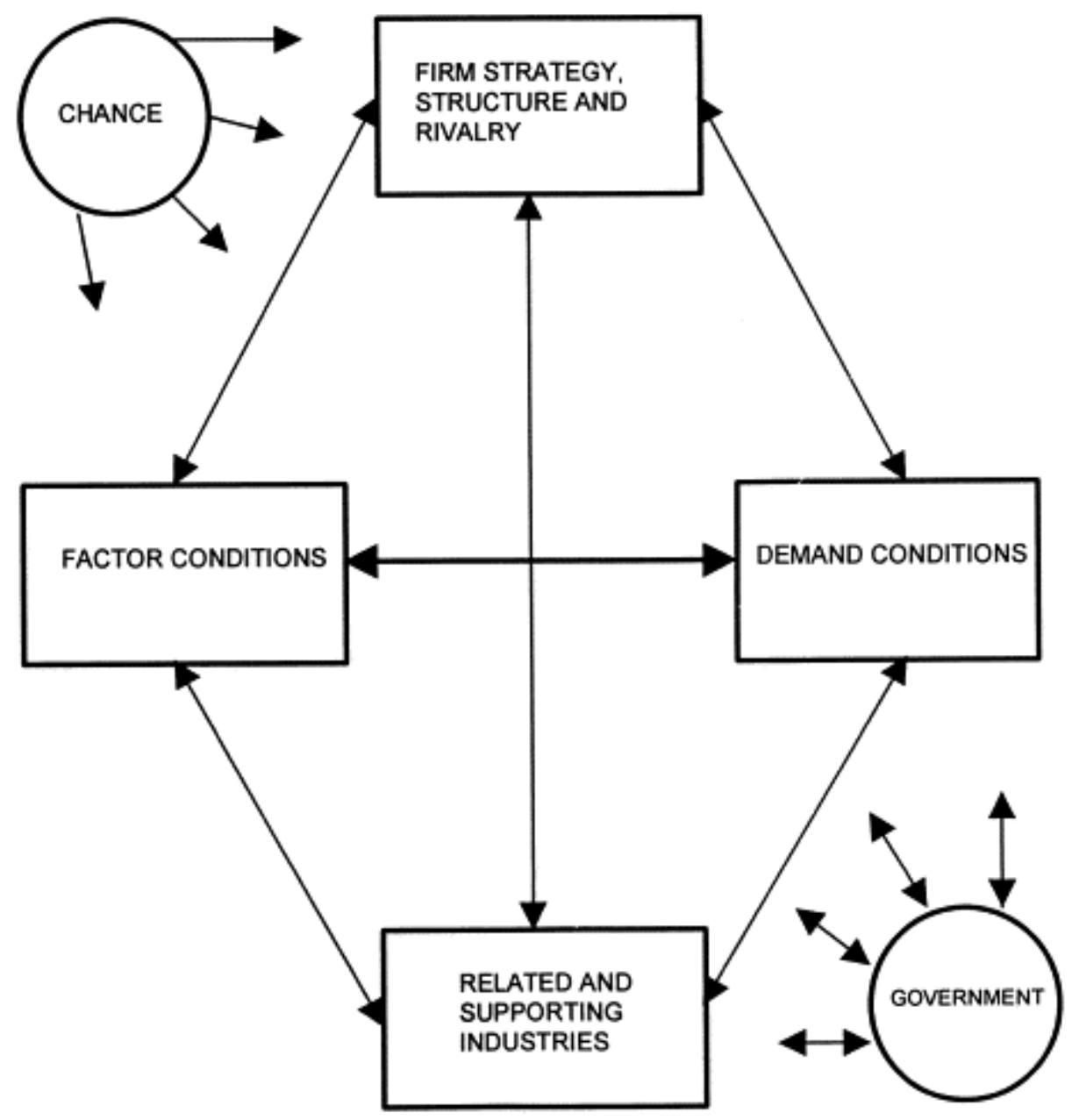

(\#Figure1) Porter'S Diamond Model. Source: (Porter, 1990)

\section{Factor Conditions:}

Porter (1990) defines factor conditions as the country's resources: human resources, natural resources, knowledge resources, capital resources, and infrastructure. He divides them into two categories: basic and advanced factors. A country needs to achieve advanced factors because they determine the sustainable competitive advantage of a country. Advanced factors are significant because basic factors such as unskilled labor, raw material, climatic conditions, and water resources are inherited and require little or no new investment to be utilized in the production process. Conversely, advanced factors such as knowledge, technology innovation, capital resources, and infrastructures are created and improved through reinvestment and 
innovation to yield advanced factors. Porter (1990) claims a country with Advanced factors can achieve competitive advantage over other countries.

\section{Demand conditions:}

Some may think that if a country focuses on international competition, they might also ignore their local competition. Porter (1990) clarifies sophisticated domestic buyers will help the industry predict, foresee or even create global trends, helping a nation gain a competitive advantage. Demand conditions are the demand of the industry in the home market. Porter (1990) explains that if there is a high level of demand for goods and services, it will pressure the company to grow, innovate, and improve quality standards. These demand conditions will create competitive advantages for the nation over time.Porter (1990) found it is not only the size of the

local demand that matters but also the sophistication of the country firms within the industry. It is the composition of local demand that shapes how firms perceive, interpret and respond to buyers' needs. Local buyers can help domestic companies foresee the market, leading to achieving advantages.

\section{Related and supporting industries:}

As global trade becomes more integrated with the firms' supply chain, it is believed that goods and services can be moved and sourced. Porter (1990) claims the success of one industry can be dependent on the sustainability of related industries or suppliers within the nation. He explains it is a "cluster" of specialization around the world that leads to the world becoming increasingly integrated. According to Porter (1990), related industries or suppliers within the nation can be seen as "networks of specialized input providers, institutions and the spillover effects of local rivalry, that become the true source of competitive advantage.'(p.14) The focus 
industry will be able to create close relationships with related and supporting industries to create opportunities for innovation, upgrade, and even new products and services together.

\section{Firm's strategy, structure, and rivalry.}

Porter (1998) thinks of a firm strategy, structure, and rivalry as the most critical drivers of competitive advantage. In fact, the national competitiveness in one nation is determined by the level of the rivalry of key players in the industry. Each firm has its own set of structures and unique strategies to achieve its own competition. Porter believes the domestic rivalry between firms again is a big drive for national competitive advantage because it pushes firms to produce goods and services with quality, high, ethical standard practices.

\section{Other Factors}

Porter discovered two other factors that affect the national competitive advantage: the role of Government, and chance. They are to affect positively and/or negatively to other four factors--Factors condition; Demand conditions; Related and supporting industries; Firm's strategy structure rivalry. The role of Government and Chance can act to encourage, or even to push the country to enhance their performance to gain a competitive advantage of the focus industry, leading to creating growth of the country. Porter (1990) reminds readers these factors change quickly and do not create long-lasting competitive advantages.

\section{The role of Government}

Porter (1990) states that the Government of a nation creating regulations helps bring benefits to the industry. He claims this factor of innovation will slowly establish national advantages, which enable industries in their country to develop a strong competitive advantage internationally. Porter says the role of the Government is "to encourage- or even pushcompanies to raise their aspirations and move to higher levels of competitive performance, this 
will help the industry to achieve quality and stimulate innovation" (1990, p.24). Each country determines how companies will compete on the world market, and then influence their competitive advantage.

\section{Chance}

A pure random event that changes the structure of the industry and causes a transformation in the level of national competitive advantage both negatively and/or positively. Porter (1990) explained Chance factors happen over a short period of time and could have a long-lasting ripple effect on the industry. 


\section{Method:}

The method section explains how and what I used to collect information. It will start by explaining the different research methods and then it will describe how I collected the data. Lastly, the credibility will be discussed and the limits of the study will be mentioned in this section.

\section{Methodological approach:}

The research design is the description of how the research process will be completed. It is a framework that includes the considerations that led to the research methodology. This paper framework is an abductive approach. (\#Figure2) The chosen approach is being used in order to answer our thesis question. Timmermans \& Tavory (2012) explains how the approach is a way of searching for an intermediate component, between data and theory, finding an explanation which itself can be shown to be true or viable.

(\#Figure 2) Abductive approach framework.

This approach is relevant because we started observing the footwear industry in Vietnam and the effect of The pandemic in the introduction of the research question. This matches with the observation stage in the drawing. Bryman and Bell (2015) mention in an abductive approach, the research process starts with 'surprising facts' or 'puzzles,' and the research process is devoted to their explanation. Then, we will find in empirical findings a combination of secondary research and primary data about the topic. These data will be compared and applied to the theory we have chosen: Porter's Diamond model. This is what matches with the third stage (Theoretical insight) in the drawing. Finally, our analysis will allow us to identify the answer to our question 
using the current framework. Finding it will help us to understand the current Vietnam footwear industry and identify opportunities to achieve advantages. I think the abductive approach is relevant for my paper because it permits the "best" explanation, and not the only one, of how Vietnam's footwear industry can achieve competitive advantages in the future.

\section{Methodological strategy: Quantitative and qualitative}

The qualitative approach involves collecting and analyzing non-numerical data to understand the concept, opinion, or experience. Parasuraman (1991) explains the method is used when the researcher wants to go through the details of his or her investigation. It is a form of exploratory research involving small samples and non-structured data collection procedures. Exploratory research is meant to gather information on real-world examples. Liz (2017) mentions, from realistic scenarios, readers can understand through a particular approach, they could do more to bring their teachings to life through connecting with business problems and cases. The qualitative method will consist of three kinds of data collection: in-depth and open-ended interview, direct observation; and written document (Patton, 1987).

A qualitative approach will be significant as the paper uses an abductive approach to answer the research question. We need qualitative data from written documents to support and explore opportunities for the Vietnam footwear industry after the pandemic 2019-2020. Qualitative data is descriptive and regards phenomena that can be observed but hard measured, such as language. No numerical data can explain how one feels and reacts to the problem.

On the other hand, quantitative data is information explained using numbers. Quantitative data can be interpreted with statistical analysis, and since statistics are based on the principles of mathematics, the quantitative approach is viewed as scientifically objective, and rational (Carr, 1994). It helps describe patterns, relationships, and connections of the study to the topic. 


\section{Data Collection Strategy:}

My thesis paper contains two different types of data: primary and secondary data. This section will explain the difference between these two data collections, and how we are going to collect them.

\section{Secondary data:}

Secondary data are information that already exists when we start our research. The secondary analysis gives researchers the opportunity to investigate research questions using large-scale data sets that are often inclusive of under-represented groups while saving time and resources (Donnellan \& Lucas, 2013). Using data from other studies, I will build hypotheses answers for my paper, to help the investigation.

Secondary data on the footwear industry, the country Vietnam, and Vietnam footwear industry are found over a number of reports and articles. Reports used to gather numbers and statistics data are Report Global Footwear Market, Mintel, World Footwear Yearbook 2020, and KPMG. Articles from Harvard Business Review, McKinsey, The World Bank, International Journal of infectious diseases, and Vietnam's Leather, Footwear and Handbags Association, help create and explain insight and explain the data reported. Data will apply to our theory, Porter's Diamond model, to help us understand the level of the competitive advantage the Vietnam footwear industry has.

\section{Primary data:}

Primary data are collected from first-hand sources. Haradhan wrote, "primary sources are firsthand information or direct evidence” (Haradhan, 2018, p.15). Primary data can be collected through questionnaires, surveys, interviews, or observation. In business, primary sources provide 
information about what a company or industry says about itself. Examples include annual reports, financial statements, press releases, interviews, speeches, blog entries, or tweets.

Our primary data will be focused on companies' annual reports. Nike, Adidas, Puma, ASIC annual reports are true reports of how the company operates and discusses the company's financial performance during the previous year with information about plans for the company's future direction. It is important to have this data because it will show key companies' structure and strategies in the footwear industry. Compare results from theory: Diamond Porter and companies' reports will help readers understand how the Vietnam footwear industry can achieve a competitive advantage.

\section{Limits of the study}

However, there are some weaknesses to this research. On the contrary, the qualitative approach is concerned with more structure and a larger number of respondents. This paper is limited to only companies' annual reports, making the data very limited. Goddard and Melville (2004) argue standards statistically accepted required numbers to establish a significant result, but due to limited resources, this paper approach implies that there is a single "truth" in the society. This study will be a focus on the footwear industry but on Nike specifically because they are one of the most recognizable footwear brands globally. 


\section{Empirical Data:}

This section will help to identify opportunities for the Vietnam footwear industry to achieve a competitive advantage first by conducting an industry outlook, then focusing on Vietnam and the nation's footwear industry, and finally looking at how the industry was disrupted by the effect of the pandemic 2019-2020,

\section{Footwear Outlook.}

Footwear serves the purpose of protecting a person's feet against the adversities of the environment. They are commonly made of leather, textiles, and a range of synthetic materials. Footwear, as the second most crucial fashion segment within the retail business just behind apparel, is also used for fashion, adornment, and to indicate the status, rank, lifestyle, or beliefs of a person within a social structure. Consequently, the footwear industry is a large and rapidly changing industry. Footwear brands and retailers play a considerable role in the success of the footwear industry and startups such as Allbirds, New York-based Koio, Nothing New, and Cariuma are gaining increasing popularity. They add value to this market by contributing numerous products, varieties, advertising campaigns, and commitment to social responsibilities. Statistics' report, Global Footwear Market, by Shahbandeh (2021) found that the footwear industry has gained immense popularity due to growing sports activities and advancements in technology fueled by social media marketing. These factors are expected to boost the global footwear market during the future period.

The footwear industry is experiencing a speedy expansion, owing to the rise in demand for trendy and comfortable footwear among all demographics. DeSalva from Mintel, author of the reports: Men's \& Women's Footwear: Incl Impact of COVID-19 - US - May 2020 (2020), claims the worldwide footwear market realized total revenue of US\$439 billion in 2019 and is 
projected to grow to US\$565billion in 2025. According to Shahbandeh (2021), the global footwear industry is forecast to grow at a compound annual growth rate (CAGR) of 5.5\% from 2020 to 2027. The biggest reason for this growth is due to the increasing number of new start-up brands in the industry, which are strengthening the footwear industry presence in retail, especially in the e-commerce sector alongside big brands. Engaging customers through social media platforms has changed the industry's focus from cost reduction to innovation and social responsibility.

DeSalva's (2020) data indicates that the Asia Pacific region is projected to be the fastest-growing, as well as largest, regional market from 2019 to 2025 in the footwear market. In fact, the Asia-Pacific region accounted for about $41.4 \%$ of the global footwear market share in 2019 and is expected to grow at a CAGR of $6.5 \%$ (DeSalva, 2020). This is $1 \%$ higher than the global average CAGR of 5.5\%. DeSalva also claims that footwear in Asia will be the fastest-growing region worldwide (2020). Supporting DeSalva's claims, The World Footwear Yearbook, a comprehensive report that analyses the main trends within the footwear sector around the world (\#Figure 3), shows that Asia is leading the world footwear consumption with 54\%, followed by North American and Europe at 14.8\% (World Footwear, 2020).

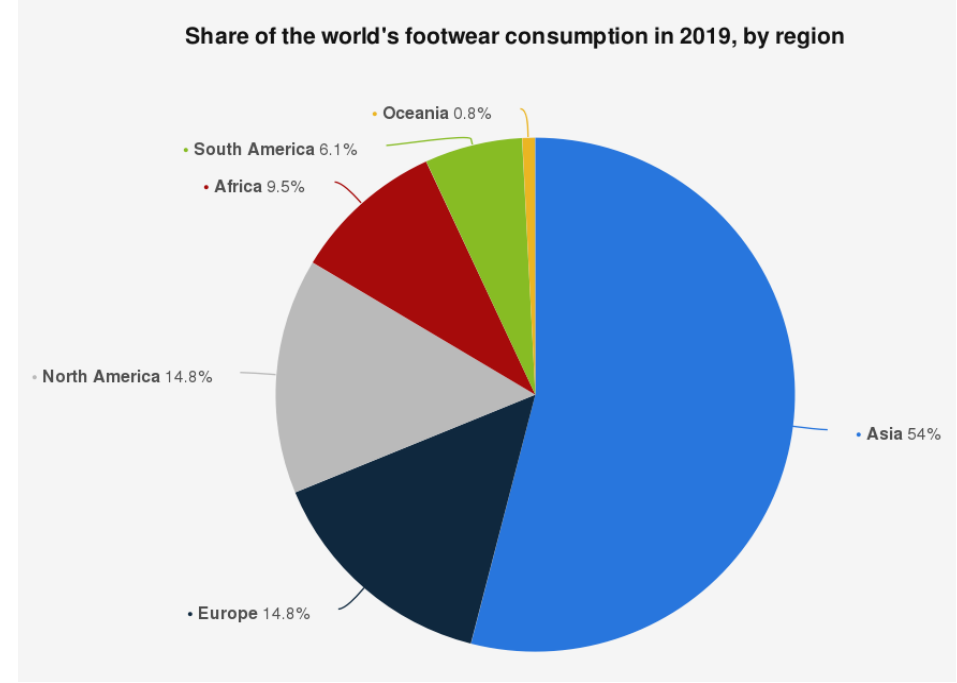


(\#Figure 3) Source: (World Footwear, 2020)

DeSalva's (2020) report breaks down the footwear industry into four segments: sneakers, athletic footwear, leather, and textile \& others. The largest segment, 39\% of global footwear, is textile \& other footwear, with market revenues of US $\$ 172$ billion in 2019 , followed by the Leather Footwear segment (US\$146 billion) and Sneakers (US\$70 billion). The smallest segment is Athletic Footwear (US\$52 billion) (DeSalva, 2020) (\#Figure 4). Shahbandeh (2021) has praised brands' recent clever marketing campaigns that have lead to sustainable levels of brand loyalty and trends, pointing to the highest growth potential in the sneakers segment, which is expected to increase by $48 \%$, reaching US $\$ 103$ billion in 2025 . Shahbandeh also claims the other segments within the footwear market will grow significantly, by more than $10 \%$ between 2019 and 2025 (Shahbandeh, 2021).

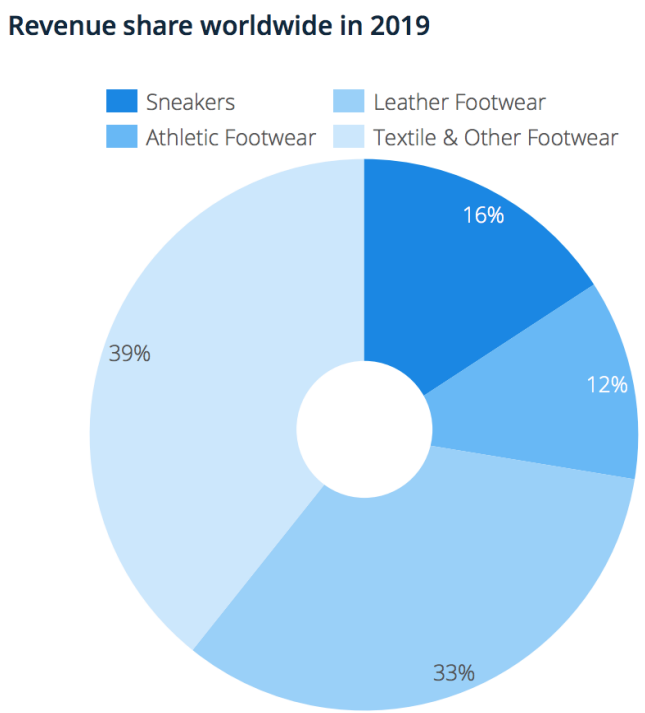

(\#Figure 4) Source:(DeSalva, 2020) 


\section{Global footwear.}

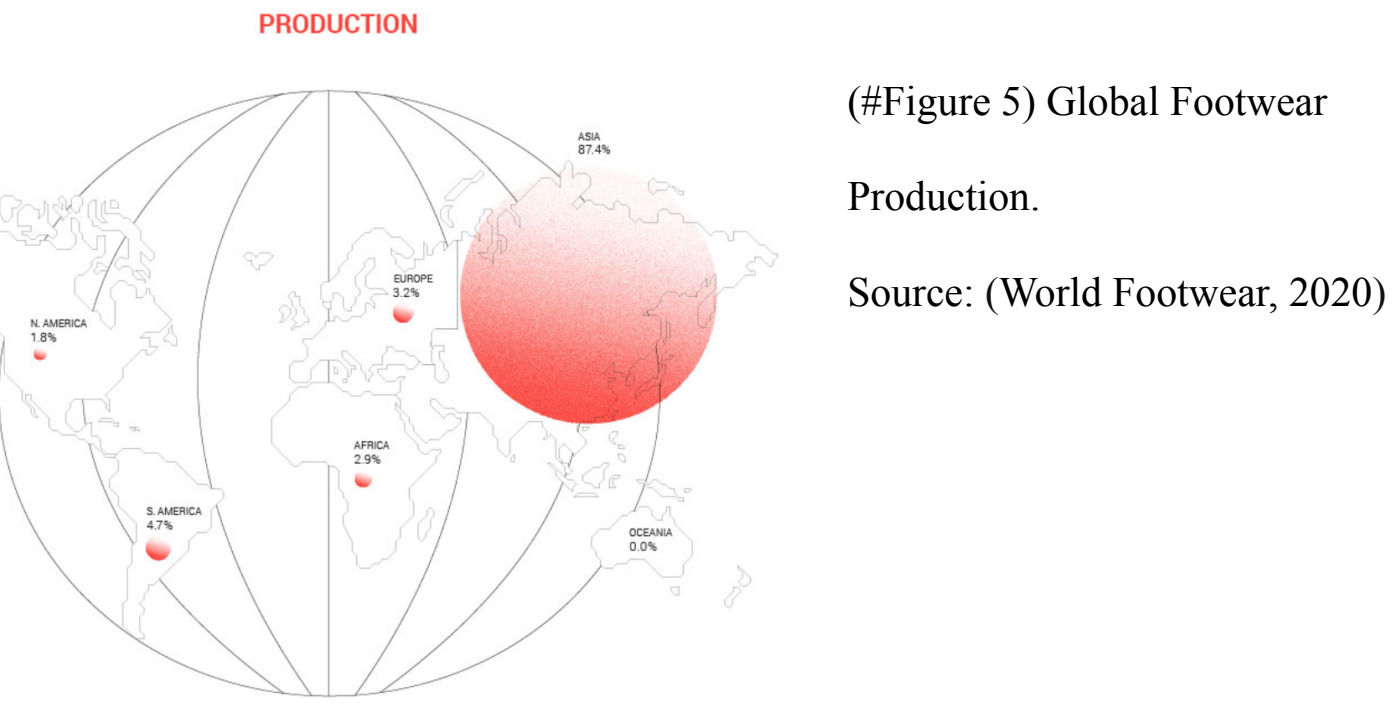

The World Footwear Yearbook reported in 2020 that the global economy underwent a sea-change with the weights of GDP and consumer spending shifting away from established markets like North and Central America and Western Europe to emerging economies in Asia, Eastern Europe, the Middle East, Africa, and Latin America (World Footwear, 2020). The World Footwear Yearbook goes on to show the production for the worldwide footwear market is of rising significance. Production in 2019, by region, is focused on Asia as $87.4 \%$ of all footwear is manufactured in the red zone (World Footwear, 2020)(\#Figure 5). International trade has greatly favored the world footwear industry. McKinsey reports in China and the World: Inside the dynamics of a changing relationship (2019) that China has been the largest exporter of goods in the world since 2009. It also is the primary exporter of footwear worldwide. Data from The World Footwear Yearbook claims that production in China, India, Vietnam, and Indonesia accounted for over 75\% of footwear production worldwide as of 2019 (World Footwear, 2020). Looking at the data from the top 10 national leading footwear producers worldwide from 2013 to 2019 , we can see that the number of footwear products by China has reduced by $15.25 \%$ from an 
all-time high in 2014 of 15,700 million pairs to 13,475 million pairs in 2019. According to McKinsey (2019), over the past several years China has faced rising labor costs and the escalation of the country's trade dispute with the U.S., causing many brands to shift their manufacturing to Southeast Asia. The World Footwear Yearbook supported McKinsey's claims by reporting that the growth of footwear exported from Vietnam and Indonesia has significantly increased between 2013-2019; Vietnam has increased their production by 58.06\%, and Indonesia by $54.77 \%$ (World Footwear, 2020) (Table\# 1).

\begin{tabular}{|l|c|c|c|c|c|c|c|c|c|c|c|}
\hline \multicolumn{2}{|c|}{ Leading 10 footwear producers worldwide from 2013 to 2019, by country (in million pairs) } \\
\hline & China & India & Vietnam & Indonesia & Brazil & Turkey & Pakistan & Bangladesh & Mexico & Italy & Thailand \\
& & & & & & & & & & & \\
\hline $\mathbf{2 0 1 3}$ & 14,200 & 2,065 & 770 & 700 & 900 & 300 & 370 & 298 & 245 & 202 & 127 \\
\hline $\mathbf{2 0 1 4}$ & 15,700 & 2,065 & 910 & 724 & 900 & 320 & 386 & 315 & 245 & 197 & - \\
\hline $\mathbf{2 0 1 5}$ & 13,581 & 2,200 & 1,140 & 1,000 & 877 & 350 & 366 & 353 & 251 & - & 200 \\
\hline $\mathbf{2 0 1 7}$ & 13,523 & 2,409 & 1,100 & 1,083 & 909 & 400 & 398 & 428 & 259 & 191 & - \\
\hline $\mathbf{2 0 1 8}$ & 13,478 & 2,579 & 1,300 & 1,271 & 944 & 447 & 411 & 461 & 268 & 184 & - \\
\hline $\mathbf{2 0 1 9}$ & 13,475 & 2,600 & 1,400 & 1,228 & 908 & 535 & 481 & 407 & 251 & 179 & - \\
\hline
\end{tabular}

(Table\# 1) *Italy and Thailand data is empty for some years as these countries do not always feature in the top ten list provided. * Source: (World Footwear, 2020) 


\section{Key Players:}

The footwear industry is highly competitive on a worldwide basis and market participants must focus on product differentiation and product development to gain a competitive advantage. Nike, one of the most recognizable footwear brands, claims on their Form 10-K 2020 (2020), that the key companies in the footwear industry include themselves, Adidas, Anta, ASICS, Li Ning, lululemon Athletica, Puma, Under Armour, and V.F. Corporation, among others. This claim is supported by DeSalva's (2020) data of consumers' favorite footwear brands which aligne with the industry's top competitors in the industry, with Nike and Adidas topping the list, along with athletic and casual shoes. Key players' competitive advantages are attributed to more than just the footwear products; both brands have established a footwear lifestyle countless consumers subscribe to by offering unique services and experiences that enhance the product and go beyond the purchase. Another way to identify the top brands in the industry is to compare their footwear revenue to that of their competitors. Nike with competitive advantages leads the industry with generating revenues of over 23.31 billion U.S. dollars in 2020. Nike's revenue is greater than the combined footwear revenue of all three of its rivals, (Table \#2). In 2020, Adidas, Puma, and ASICS made global sales of only 13.67 billion U.S. dollars, 2.91 billion U.S. dollars, and 3.15 billion U.S. dollars respectively (Table\# 2). 


\begin{tabular}{|c|c|c|c|c|}
\hline \multicolumn{5}{|c|}{ Revenue from footwear segment 2010 to 2020 (in billion U.S. dollars) } \\
\hline & Nike & Adidas & Puma & ASICS \\
\hline $\mathbf{2 0 1 0}$ & 11.52 & 7.14 & 1.89 & 2.16 \\
\hline $\mathbf{2 0 1 1}$ & 13.43 & 8.13 & 1.99 & 2.42 \\
\hline $\mathbf{2 0 1 2}$ & 13.51 & 9.15 & 2.11 & 2.73 \\
\hline $\mathbf{2 0 1 3}$ & 14.64 & 9.46 & 1.88 & 2.61 \\
\hline $\mathbf{2 0 1 4}$ & 16.21 & 8.09 & 1.56 & 2.95 \\
\hline $\mathbf{2 0 1 5}$ & 18.32 & 9.13 & 1.65 & 2.53 \\
\hline $\mathbf{2 0 1 6}$ & 19.87 & 10.67 & 1.71 & 3.82 \\
\hline $\mathbf{2 0 1 7}$ & 21.08 & 14.89 & 2.41 & 3.83 \\
\hline $\mathbf{2 0 1 8}$ & 22.27 & 14.62 & 2.5 & 3.7 \\
\hline $\mathbf{2 0 1 9}$ & 24.22 & 15.14 & 2.86 & 3.62 \\
\hline $\mathbf{2 0 2 0}$ & 23.31 & 13.67 & 2.91 & 3.15 \\
\hline
\end{tabular}

(Table\# 2)

**Source: Data was collected from the company's annual reports.**

**ASICS data was converted from Yen to USD at 0.0093 United States Dollar per Yen. (4/29/21)

\section{Footwear supply chain:}

There are many different types of footwear offered in the market and each has a different purpose and style. The variety of products have created a complex footwear industry global supply chain. The efficient relationship between suppliers-producers-retailers conforms to the perfect combination to achieve a high level of competitiveness through timely response to the needs of increasingly demanding and changing markets. Many companies source raw materials and components from various countries around the world, often engaging with hundreds of suppliers through a number of tiers. Take Nike's upstream supply chain as an example (\#Figure 6). According to the Nike manufacturing map (2021), its finished products are made from components from 39 countries produced at 486 independent factories and by more than 1 million 
workers. Nike reported on their Form 10-K 2020 (2020) the company's strategy is to outsource $100 \%$ of its manufacturing of footwear and apparel to independent contractors suppliers. Nike's outsourcing strategy creates an extensively diversifying supplier base, mitigating the risk of product shortages from unpredictable occurrences, such as accidents and extreme weather events. According to its Form 10-K 2020 (2020), Nike's footwear components in 2019 were supplied by 112 different factories in 12 countries, $96 \%$ of its footwear - made in Vietnam, China, and Indonesia. A high number of factories help to mitigate the risks as no single facility accounts for more than $9 \%$ of the branded footwear (Nike, Inc, 2020). However, there are challenges to this approach that come from Nike's supply chain in tier 2 and 3 suppliers. Beyond the manufacturing process itself, Nike relies upon independent contractors to source the raw materials for its products from a number of countries in which they're produced. After shoes have been manufactured, often they are shipped using ocean freight to 57 Nike's distribution centers around the globe, entering downstream, where goods go from the organization to the customers.

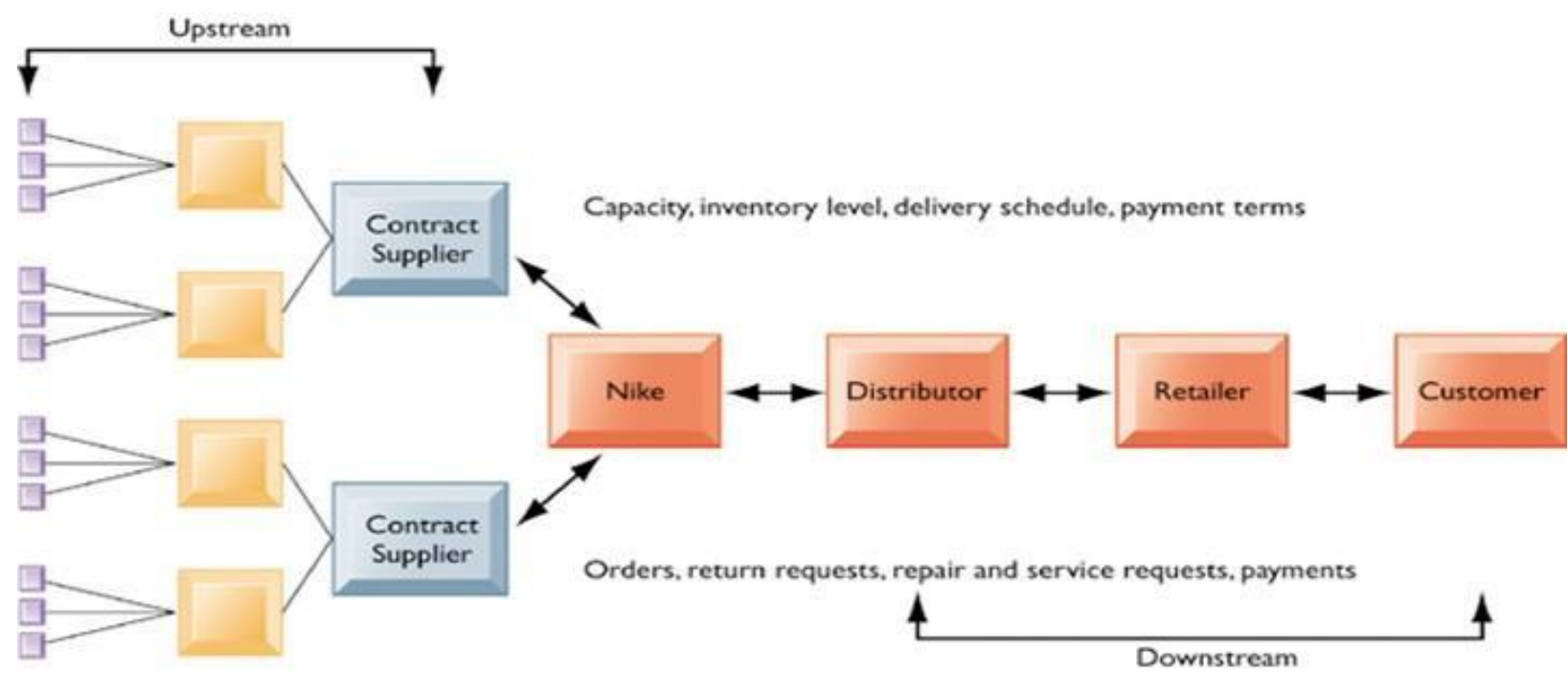

$\begin{array}{lll}\text { Tier } 3 & \text { Tier } 2 & \text { Tier 1 } \\ \text { Suppliers } & \text { Suppliers } & \text { Suppliers }\end{array}$

(\#Figure 6) Nike’s Supply chain. Source: (Laudon, K. C., \& Laudon, J. P., 2018) 


\section{Capability in Vietnam's footwear industry}

\section{Vietnam Outlook}

Vietnam is the focus of this paper due to its rapid economic growth as a result of economic and political reforms undertaken under Đổi Mới and launched in 1986 by Vietnam’s Government. According to The World Bank (2021) overview of Vietnam, one of the world's largest sources of assistance funding and knowledge for developing countries, Vietnam has transformed from one of the world's poorest nations into a lower-middle-income country. Consequently, China's rising production costs and increasingly complex Government regulations have led to Vietnam rising as a serious competitor in the footwear industry (McKinsey, 2019). The country is located in the heart of South East Asia with approximately 127,882 sq miles, the capital city Ha Noi, and 63 Provinces/Cities. It also has direct access to the coastline of the Pacific Ocean and China's neighbors and therefore offers numerous advantages in providing access to the world's major trade routes (World Bank, 2021).

\section{Economic:}

The Organisation for Economic Co-operation and Development (OECD)(2009), an intergovernmental economic organization with 37 member countries, uses the Gross domestic product (GDP) as the standard measure of the value of final goods and services produced by a country during a period. GDP growth rate is an essential indicator of a country's economic performance. OECD (2009) explains GDP will grow as positive changes in the volume of production in an economy. KPMG (2021), a global network of professional firms providing audit, tax, and advisory services,praised Vietnam for its growth rate of $7.1 \%$ GDP in 2018, when the global trade recession and China's economic growth slowed down, the country achieved its highest rate in nearly ten years(\#Figure 7). The World Bank (2019) overview of Vietnam in 
2019, reported the GDP in Vietnam was worth 261.92 billion U.S. dollars in 2019 (7.017\%) and projected a GDP growth higher than the global average at around 6.5 percent over the next few years due to the high volume of foreign direct investment (FDI). The World Economic Outlook reports (2020), in 2020 forecasted the Global GDP growth before covid is to rise from an estimated 2.9 percent in 2019 to 3.3 percent in 2020 and 3.4 percent for 2021. The World Bank explains that Vietnam's GDP growth has continued to be driven by its solid export sector, with exports expanding by about 8 percent in 2019 - nearly four times faster than the world average (World Bank, 2019 \& 2021).

Vietnam is considered one of the fastest and relatively stable-growing economies in Asia over the past years looking at the country’s GDP. KPMG (2021) pointed out the turning key point for Vietnam was the accession to the World Trade Organization in 2007. Joining WOT has created opportunities for foreign investors, causing the county to expand and advance at an incredible speed. The country's economy will grow by rising consumption, boost FDI, creating robust export performance, deeper integration into the global economy, and improvements of the regulation system.

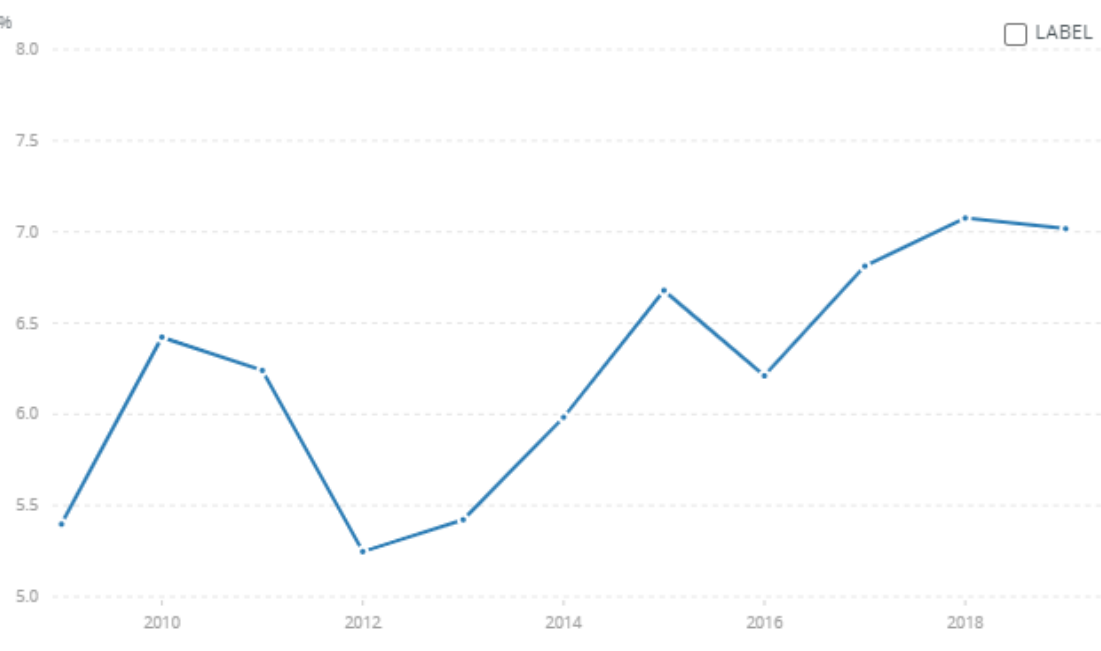

(\#Figure 7) VietNam GDP 2009-2019Source: (World bank, 2021) 


\section{Labor: population, education level.}

KPMG (2021), showed Vietnam's total population reached 96.5 million in 2019 and is estimated to increase to 98.2 million by 2021. People in Vietnam speak Vietnamese and are obligated to learn a popular foreign language as a second language. A KPMG (2021) data show Vietnam in 2019 shows that more than $96 \%$ of the Vietnamese population aged 15 and older is literate. Vietnamese Government's continued efforts to prioritize the development of a quality training and educational system. To increase the level of efficiency working with foreign investors, English lessons are offered and mandatory in most schools, and other typical study foreign languages are French, Chinese, and Japanese.

Low wages are the main reason companies were there in the first place. It indicates that the Vietnamese export industry enjoys labor advantages and significantly increases the comparative advantages of middle- and low-grade products such as footwear, apparel, or electrical machinery. Katelynn Harris and Michael D. McCall (2019) reported that in 2018, the United States manufacturing sector hourly wages hovered on average 21.54 U.S. dollars, an 18.81 dollar difference compared to Vietnam hourly wages, which were less than three U.S. dollars. The labor costs in the U.S. are higher for companies as they look to cut costs and make higher profits, targeted by countries such as China, Mexico, and Vietnam with cheaper labor to invest in (\#Figure 8). As a result of the lowest labor cost from the three, many manufacturers have turned to new suppliers in Vietnam for low-wage. It makes Vietnam a new hub for foreign companies to focus on and invest in. 
Manufacturing labor costs per hour for China, Vietnam, Mexico from 2016 to 2020 (in U.S. dollars)

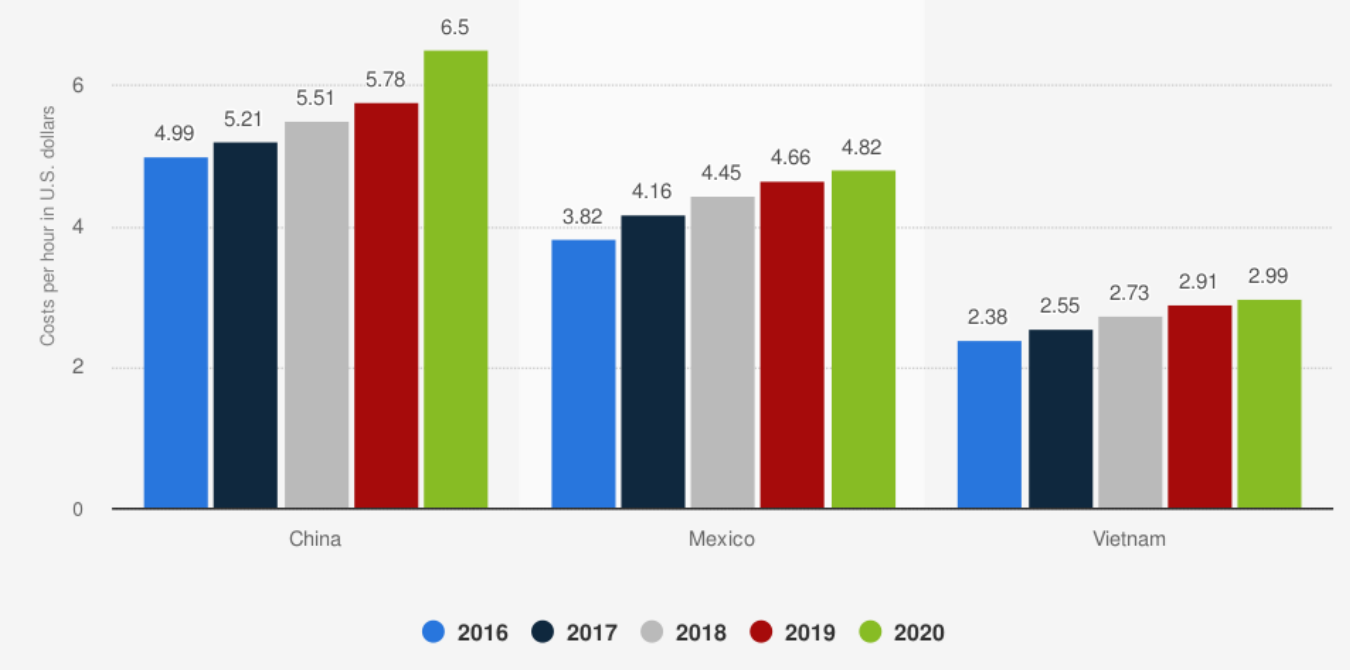

(\#Figure 8) Manufacturing labor costs per hour for China, Vietnam, Mexico from 2016 to 2020 (in U.S. dollars) Source: (SourceToday, 2017)

\section{Infrastructure:}

It is crucial to building a stable infrastructure system to support the country's growth. Hong, Chu, and Wang (2011) suggest that economic policies that improve transport infrastructure impacted per capita income convergence. Hong, Chu, and Wang's (2011) study on the significance of infrastructure showed that land transport infrastructure has the most significant impact on economic development, followed by water transport, while the impact of airway transport infrastructure is insignificant. This might be due to the high cost of transaction logistics by airways. Better transport infrastructure will attract investments. Many companies value reducing transaction costs on trade and abilities to scale down lead-time are ways to cut costs and create a competitive advantage. According to KPMG (2021), the Vietnam Government is planning to expand and upgrade the existing transportation infrastructure system. Vietnam 
plans to improve its road infrastructure by building a major national road, Highway No. 1A, connecting the China border to Ho Chi Minh City. No. 1A will connect the North with the South; linking key economic regions will increase efficiency and communication within the country, providing Vietnam a faster lead time from China's resources. Vietnam's sea transportation plays a significant component in the Vietnamese infrastructure system. Most of the country's trade involves ocean freight. Vietnam has a location advantage, achieving over 100 ports throughout the country, of which the major ones are located in Hai Phong, Da Nang, and Ho Chi Minh City (KPMG, 2021). Due to the increase in demand of exporters, Vietnam's plans to upgrade and expand the existing capacity are underway; this support with their commitment is to develop the mega-port Hon Khoai in Ca Mau province. The country is building its biggest airport (Long Thanh Airport) to prepare for increased air transportation and travel. Long Thanh Airport is estimated to accommodate up to 25 million passengers and 1.2 million tons of cargo a year (KPMG, 2021). Higher economic growth leads to more Government revenue and greater demand for good infrastructure, which stimulates further improvement of transport conditions.

\section{Regulation:}

In terms of regulatory and financial incentives, Vietnam has become increasingly investor-friendly in recent years. The Vietnamese Government has taken such actions as reforming its financial sector, streamlining business regulations, and improving the quality of its workforce. Adding to that, KPMG (2021) mentioned the effort of the Vietnamese Government in boosting international economic integration through the participation in many free trade agreements (FTA). FTA is an agreement between two or more nations focused on organized and reduced tariffs of goods, it also includes regulatory compliance and services for the parties to benefit from each other. After joining the World Trade Organization in 2007, Vietnam has been 
active in signing bilateral trade agreements with countries throughout the world, becoming a member of 12 different FTAs, such as the Comprehensive and Progressive Agreement for Trans-Pacific Partnership (CPTPP), EU-Vietnam FTA (EVFTA), and UK-Vietnam FTA (UKVFTA) (WTO, 2021). Vietnam took advantage of the reduced tariffs, both within the ASEAN community and with the E.U., to attract foreign companies to produce and invest in goods and services in Vietnam, leading to quick route export to partners outside ASEAN (\#Figure9). Xuan, Cuong, and Long claim (2016), the value of having FTAs play an essential role in helping the country's footwear industry growth. FTAs will help Vietnam move up the value chain in several sectors and make the transition into supporting high-skilled jobs and knowledge transfer. Government promoting FTA led to a significantly increasing FDI. Xuan, Cuong, and Long (2016) called this would be a "golden" opportunity for Vietnam to develop in quantity, create innovation, and quality goods and services. KPMG (2021) supports Vietnam's commitment to global integration by claiming the Vietnamese legal framework is changing to be more transparent and conform to international standards. The Comprehensive and Progressive Trans-Pacific Partnership Agreement (CPTPP) has expanded Vietnam's footwear export market to Mexico, Canada, Chile, and Peru in 2018, playing a big part in how the Footwear industry recorded stable growth and maintained its competitive edge in Vietnam markets. According to the World Footwear report, Vietnam is already taking advantage of the US-China trade war, Vietnam signed The EU-Vietnam Free Trade Agreement is a free trade (EVFTA) means " $65 \%$ of import duty lines for Vietnamese footwear imported to the EU will be zero \% immediately from effectiveness, and $100 \%$ of import duties for footwear will be eliminated after 7 years from the effectiveness" (2019, p.1) This will create favorable conditions to expand Vietnam's footwear to the EU. In comparison with other exporter countries, especially China, (\#Figure 10) Vietnam's 
export industry benefited greatly from FTAs, creating opportunities for jobs and prosperity for the Vietnamese people. The country shows commitments to improving topics such as tariff reductions, investor protection, and trade facilitation will have a tremendous impact on exporting firms, foreign investors, and consumers in Vietnam, helping the country and its people innovate. KPMG explains Vietnam's multilateral rules-based trading system has contributed to creating its macroeconomic stability (2021).

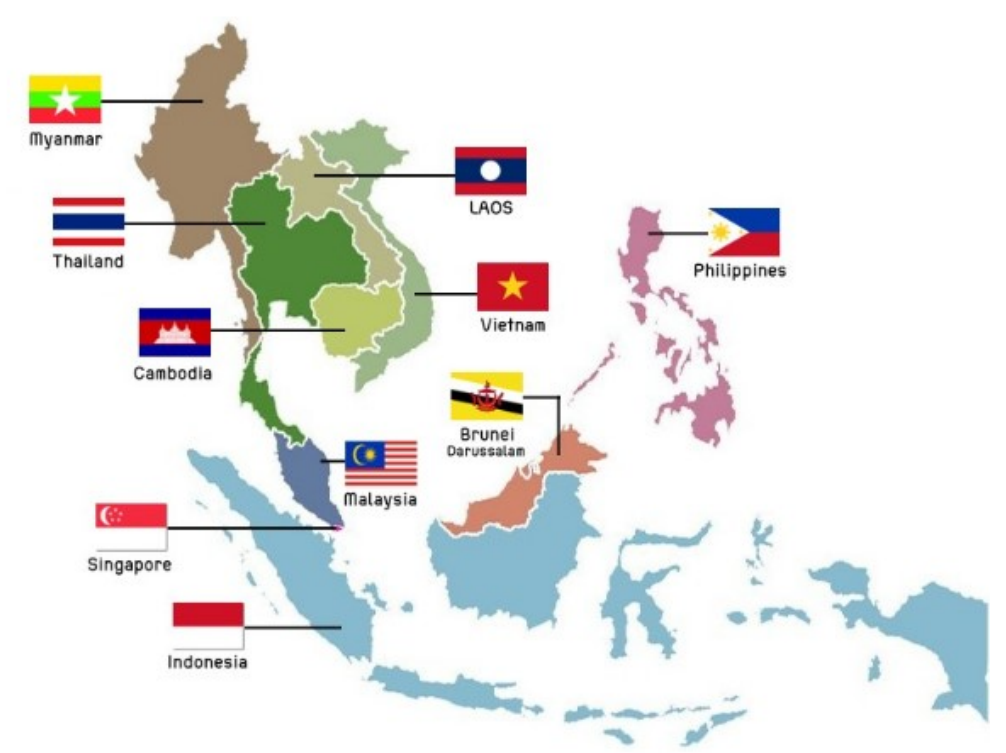

(\#Figure9): ASEAN countries.

Source: (WOT, 2020)

Image: ASEAN

\begin{tabular}{|c|c|c|c|c|c|c|c|c|}
\hline FTAs & $\begin{array}{l}\star \\
\text { VN }\end{array}$ & 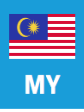 & $\overline{\overline{\text { TH }}}$ & $>$ & ID & KH & $\begin{array}{l}\star \vdots \\
\text { CN }\end{array}$ & (\#Figure 10) \\
\hline AFTA & $\sqrt{ }$ & $\sqrt{ }$ & $\sqrt{ }$ & $\sqrt{ }$ & $\sqrt{ }$ & $\sqrt{ }$ & $x$ & Comparison FTAs in \\
\hline AFTA-China & $\sqrt{ }$ & $\sqrt{ }$ & $\sqrt{ }$ & $\sqrt{ }$ & $\sqrt{ }$ & $\sqrt{ }$ & $\sqrt{ }$ & 2019. \\
\hline India & $\sqrt{ }$ & $\sqrt{ }$ & $\sqrt{ }$ & $\sqrt{ }$ & $\sqrt{ }$ & $\sqrt{ }$ & $x$ & \\
\hline Korea & $\sqrt{ }$ & $\sqrt{ }$ & $\sqrt{ }$ & $\sqrt{ }$ & $\sqrt{ }$ & $\sqrt{ }$ & $\sqrt{ }$ & source (KPIVIG, \\
\hline Japan & $\sqrt{ }$ & $\sqrt{ }$ & $\sqrt{ }$ & $\sqrt{ }$ & $\sqrt{ }$ & $\sqrt{ }$ & $x$ & 2021) \\
\hline СРТPP & $\sqrt{ }$ & $\sqrt{ }$ & $X$ & $X$ & $x$ & $x$ & $X$ & $*$ Yellow circle $=$ still \\
\hline EU & $\sqrt{ }$ & 0 & ○ & ○ & $\mathrm{X}$ & $x$ & $x$ & \\
\hline US & $x$ & 0 & 0 & $X$ & $x$ & $x$ & $X$ & under negotiation.* \\
\hline
\end{tabular}




\section{Vietnam footwear industry}

\section{Vietnam footwear manufacture:}

Vietnam's economic structure has seen a gradual shift from agriculture to the manufacturing industry. KPMG (2021) reports Vietnam GDP by sectors, $41.5 \%$ Service, $34.4 \%$ Industry, and 14.0\% Agriculture. This transition has resulted in wealth creation growth and rising consumption which is a fundamental indicator to attract foreign investors to expand business in the region. When looking at the top 5 export industries from Vietnam to the global market, we can see an increase in all manufacturing industries (Table\# 3). According to Abdulkadir, Afriana, and Aziz (2020), Vietnam's footwear export industry has a significant role in bringing in foreign exchange, as also as many Asian countries. Vietnam is the third-largest player on global footwear export in 2019, behind only China and India (Table\# 1). The EU region has been a major import market for Vietnam's footwear products for many years, second only to the US market (Abdulkadir et al, 2020). The VietNam Leather and Footwear Association (2021) estimates 2,180 enterprises in the country producing footwear, concentrated around Ho Chi Minh City provinces . Vietnamese footwear exports have increased by an average annual rate of $9.93 \%$ for the last seven years (Table\# 4), the highest compared to 4 other key countries (China, Indian, Indonesia, and Brazil). The nation's Footwear exports to more than 100 countries, 70 of which import more than 1 million USD worth of Vietnamese footwear (World Footwear, 2020). Vietnam's footwear industry is able to grow at an incredible rate due to its association with other related industries specializing in the production of fashion items, handbag, leather, textile, and apparel. The VietNam Leather and Footwear Association (LEFASO) along with Textile and Apparel Association (VITAS), develop strategies for the footwear sector in Vietnam to build and create innovation in fashion goods production. 


\begin{tabular}{|c|c|c|}
\hline \multicolumn{2}{|l|}{ Vietnam's top five exports and growth. (2019) } & \\
\hline Type of Products & Value (\$Billion) & $\begin{array}{c}\text { Year to year growth } \\
\text { (2018-2019) }\end{array}$ \\
\hline Telephones and parts & $\$ 51.4$ & $4.4 \%$ \\
\hline Computers, Electronics & $\$ 35.9$ & $21.5 \%$ \\
\hline Textiles and garments & $\$ 32.9$ & $7.8 \%$ \\
\hline Footwears & $\$ 18.3$ & $12.8 \%$ \\
\hline Machinery, Instruments & $\$ 18.3$ & $11.9 \%$ \\
\hline Total Exports & $\$ 156.8$ & \\
\hline
\end{tabular}

(Table\# 3) Source: (KPMG, 2021)

Footwear average annual growth rate of exports by country (2013-2019)

\begin{tabular}{|c|c|}
\hline China & $0.87 \%$ \\
\hline India & $3.84 \%$ \\
\hline Vietnam & $9.94 \%$ \\
\hline Indonesia & $9.31 \%$ \\
\hline Brazil & $0.14 \%$ \\
\hline
\end{tabular}

(Table\# 4) Source: (World Footwear, 2020)

\section{Domestic footwear market:}

Statista Consumer Market Outlook conducted a Footwear Report for 2020 (2020), claims the Vietnam Footwear market amounted to US\$1,212m in 2020, and from 2021-2025 is expected to grow annually by $6.42 \%$. The growing rate of footwear producers will also take responsibility for growing its domestic market. Vietnam ranks 38th in the top global footwear revenue in 2020. The nation has a very small footwear market compared to its footwear product export industry. The top five countries that generated the most revenues in 2020 are the United States (US\$86,132m), follow by China(US\$66,102m), Brazil (US\$49,653m), Japan (US\$27,933m), 
and lastly Russia (US\$15,780m) (\#Figure 11). The World Footwear Yearbook (2020) explains Vietnam footwear producers make up for its nation's absence in the market.

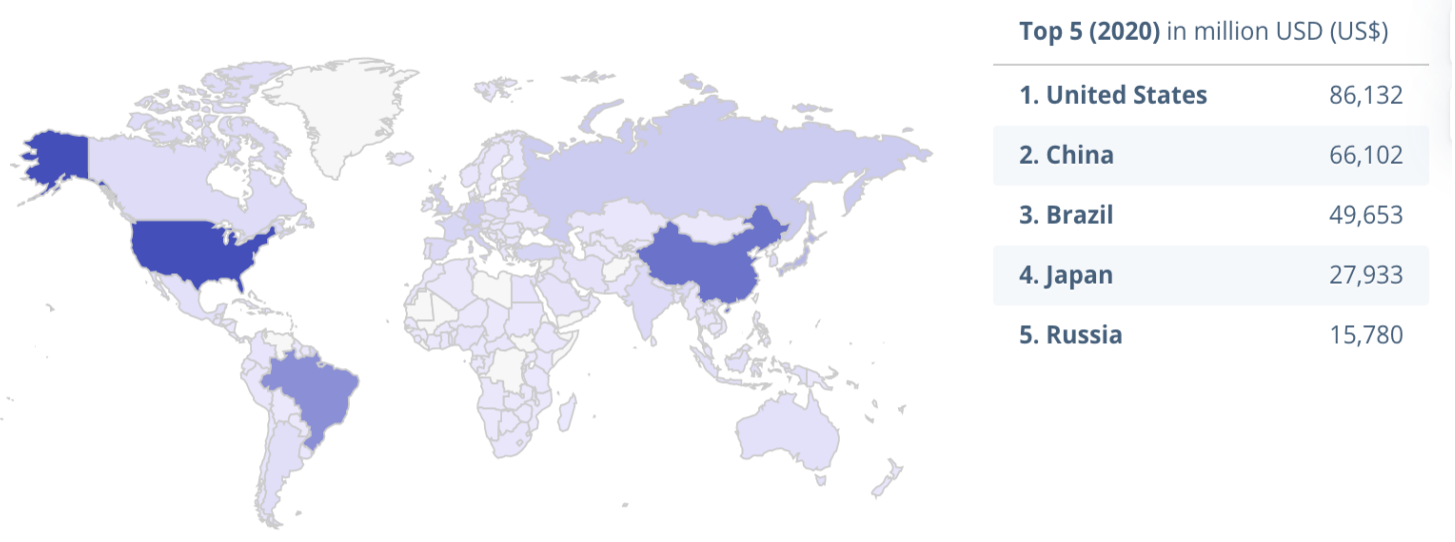

$0 \quad 25,000 \quad 50,000 \quad 75,000 \quad 10$.

(\#Figure 11) Global footwear revenue adjusted with COVID-19 in 2020. Source: (Footwear report 2020 - Vietnam, 2020)

\section{Key Player in Vietnam:}

Two key players in the footwear industry, Nike and Adidas, chose Vietnam over China for their facilities H.Q. (Nike and Adidas annual report 2020). Comparing Nike Footwear production from 2010-2020, we can see a shift out of China and an increase in Vietnam (Table\# 5). Noted, Nike doesn't own the factories, they actually contract the factories. Independent contract factories in Vietnam, China, and Indonesia manufactured approximately $37 \%, 34 \%$ and 23\% of their Nike Brand Footwear in 2010 (\#Figure 12), the numbers reported in 2019 were to be $49 \%, 23 \%$, and $21 \%$ (\#Figure 13). Clearly, Nike is making the transition into Vietnam and reducing their production in other countries, significantly $10 \%$ reduction in China over the last ten years, as Indonesia numbers stay in the 20\%-26\% range. With a large network of independent 
contract factories in Vietnam, 50\% of Nike footwear in 2020 was manufactured in Vietnam. Nike manufacturing map (2021) shows, Nike has 105 independent contract suppliers in Vietnam with 96 factories clustered in the south (Ho Chi Minh City) of Vietnam. Nike's number one competitor, Adidas, is also choosing Vietnam as their primary manufacturing region. Adidas reported in their Annual report (2020), in 2019, 98\% of all Adidas footwear is produced in the Asia region. Adidas has halved the amount of footwear it makes in China since 2010, having moved most production to Vietnam. Vietnam represents Adidas' largest sourcing country with $42 \% \%$ of the total footwear volume (2018: 43\%), followed by Indonesia with $29 \%$ (2018: 28\%), and China with 15\% (2018: 17\%). The shift means that the world's largest footwear corporations are now ditching China in favor of Vietnam, and as two key players as examples, this trend will only keep accelerating. This will increase the level of competitors in Vietnam's domestic footwear market.

\begin{tabular}{|c|c|c|c|}
\cline { 4 - 4 } & \multicolumn{2}{|c|}{ Nike Footwear Manufactured } & \multicolumn{1}{c|}{} \\
\hline & Vietnam & China & Indonesia \\
\hline $\mathbf{2 0 1 0}$ & $37 \%$ & $34 \%$ & $23 \%$ \\
\hline $\mathbf{2 0 1 1}$ & $39 \%$ & $33 \%$ & $24 \%$ \\
\hline $\mathbf{2 0 1 2}$ & $41 \%$ & $32 \%$ & $25 \%$ \\
\hline $\mathbf{2 0 1 3}$ & $42 \%$ & $30 \%$ & $26 \%$ \\
\hline $\mathbf{2 0 1 4}$ & $43 \%$ & $28 \%$ & $25 \%$ \\
\hline $\mathbf{2 0 1 5}$ & $43 \%$ & $32 \%$ & $20 \%$ \\
\hline $\mathbf{2 0 1 6}$ & $44 \%$ & $29 \%$ & $21 \%$ \\
\hline $\mathbf{2 0 1 7}$ & $47 \%$ & $27 \%$ & $21 \%$ \\
\hline $\mathbf{2 0 1 8}$ & $47 \%$ & $26 \%$ & $21 \%$ \\
\hline $\mathbf{2 0 1 9}$ & $49 \%$ & $23 \%$ & $21 \%$ \\
\hline $\mathbf{2 0 2 0}$ & $50 \%$ & $24 \%$ & $22 \%$ \\
\hline
\end{tabular}

(Table\# 5) Source: Nike, Inc. Form 10-K(2010-2020) 
2010 Nike Footwear Manufactured (by volume)

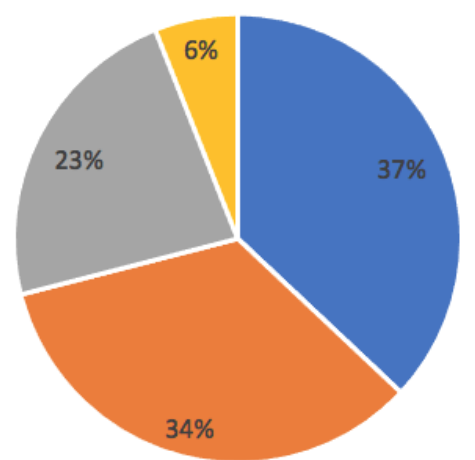

$$
\text { - Vietnam | China | Indonesia } \text { - Other: }
$$

(\#Figure 12) Source: (Nike, Inc. 2010)

2020 Nike Footwear Manufactured (by volume)

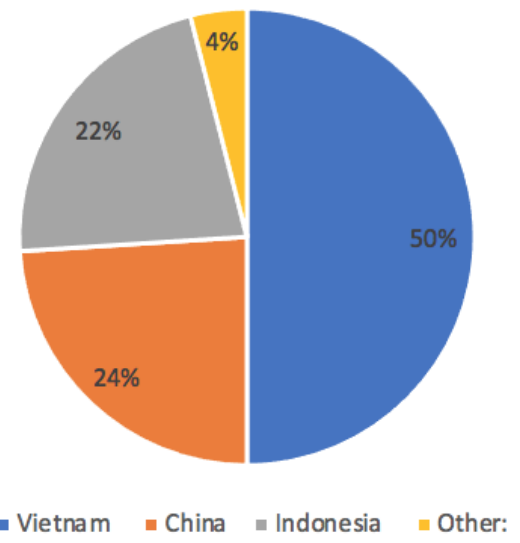

(\#Figure 13) Source: (Nike, Inc. 2020) 


\section{Effect of pandemic 2019-2020}

\section{Footwear industry:}

The Covid-19 virus has affected everyone's life greatly. The Coronavirus outbreak has severely impacted the footwear industry. The outbreak affects the footwear global industry in three main ways: by directly affecting production and demand, by creating supply chain and market disturbance, and by its financial impact on firms and financial markets. Consumers have become more conscious of their spending habits and tend to purchase mostly essential products, which is a major challenge for the market.

There is a shift in demand for footwear products after the pandemic, DeSalva (2020) expects the pandemic effect will be similar to the pattern from the 2008 recession showing there will be a downward sales trend to occur through 2020-2021, with a turnaround expected beginning in 2022. DeSalva (2020) asked 2000 users to answer the question "what type of footwear have you purchased in the past 12 months?" in their report showing athletic shoes is the highest pick rate with 53\% but also is tied with casual shoes(\#Figure 14). DeSalva (2020) explained casual wear and athletics is the new trend in the industry due to most consumers no longer dressing differently for different aspects of their life; as dress codes become less formal due to many reasons in 2020. The focus and importance of overall health and wellness will continue to increase as a result of the pandemic. Comfort and function will continue to be the growing sector as the pandemic continues.

"What types of footwear have you purchased in the past 12 months? Please select all that apply."

\section{Items Purchased}

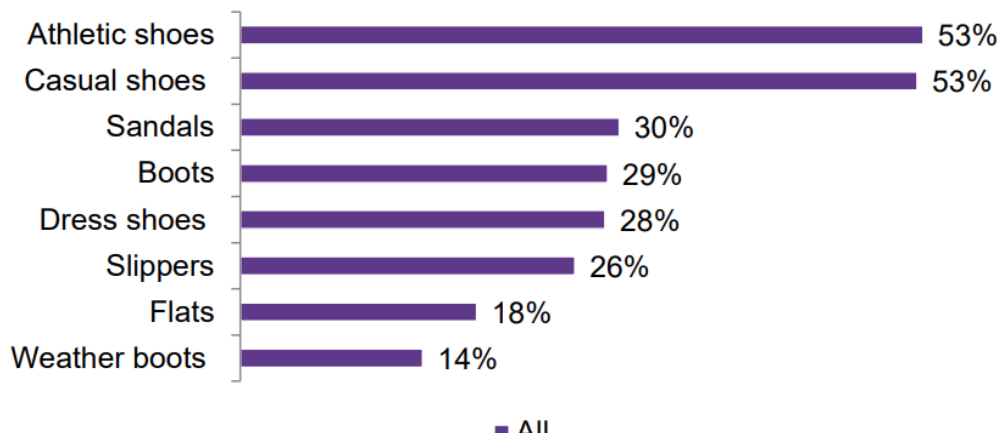

(\#Figure 13)

Source: (DeSalva,

A. 2020) 
DeSalva's found (2020), need-based shopping is a common occurrence during the prolonged pandemic; consumers are paying more attention to their own consumption. They are striving to shop locally, limit waste, aim for more sustainably, and consider costs effective, leading to shoppers may buy footwear less frequently than other items. This is supported in Nike's Form 10-K 2020, the company's biggest regional market, North America, footwear sales there reached 9.33 billion U.S. dollars in 2020. Nike explained the declines in the fourth quarter, primarily resulting from lower shipments to our wholesale customers and store closures due to COVID-19, North America revenues fiscal 2020 decreased 7\%, from 2019 (10.045 billion U.S.) (Nike, Inc., 2020). From looking at other competitors, comparing revenue from 2010 to 2020 , Nike, Adidas, and ASICS faced negative impacts in the year of 2019-2020; Puma was the only company that did not. (\#Figure 14)

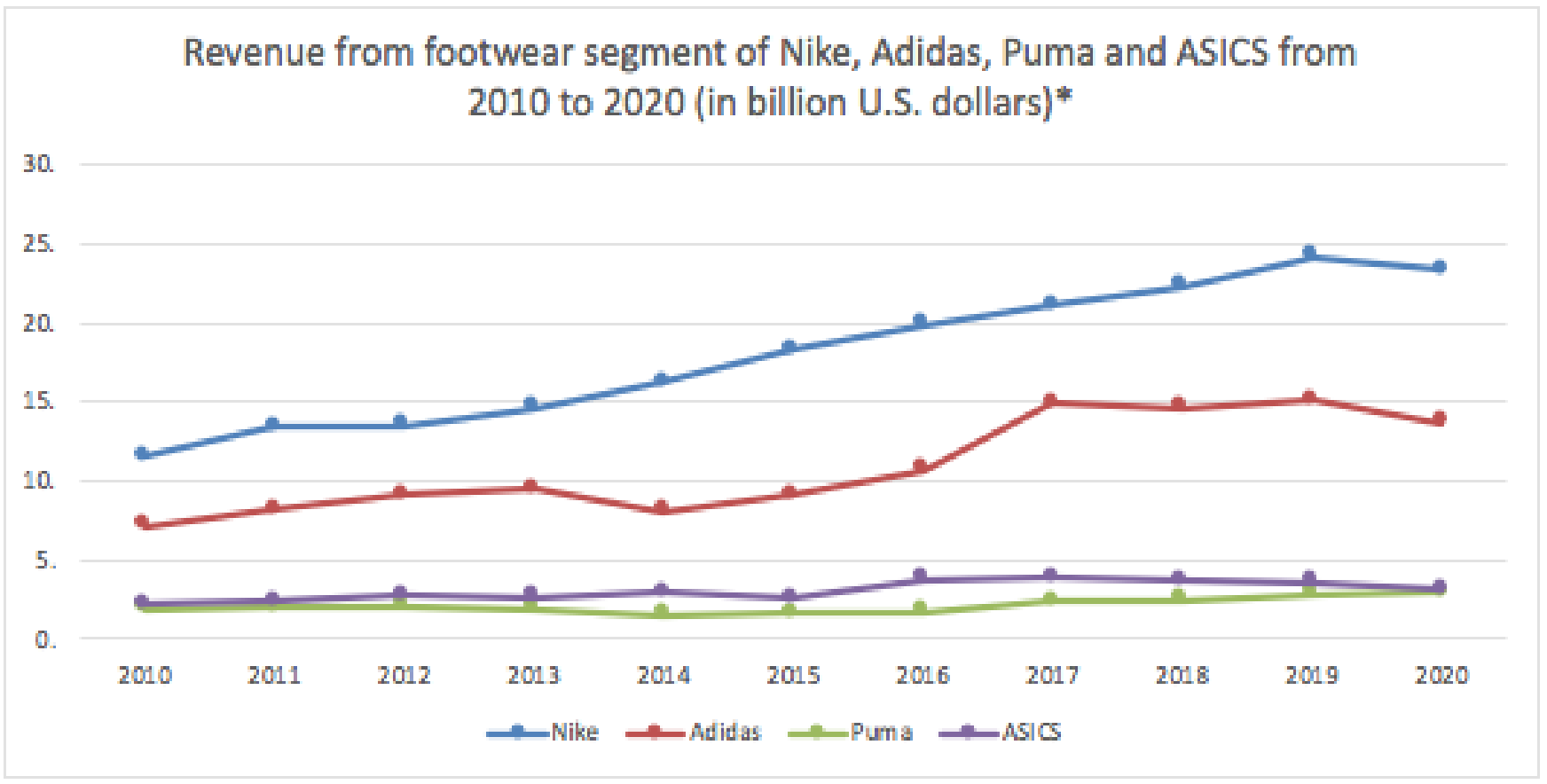

(\#Figure 14) **Source: Based on (Table 2) Data was collected from annual reports.** 


\section{Vietnam and its footwear industry:}

McKenzie (2020) states the pandemic will significantly negatively impact public health and economic growth in all markets. Nguyen, Cao, and Nghiem (2021) wrote an overview about the spread of COVID-19 and policy responses in Vietnam, claiming COVID-19 emerged in Vietnam at the end of January 2020. They reported the nation proactively fought the coronavirus, closed its borders, suspending visas and flights, and imposing social isolation measures to better contain the pandemic (Nguyen et al, 2021). The World Footwear Yearbook (2020) listed Vietnam authorities measures to mitigate the impacts of the COVID-19 in the economy by delaying tax payments; postpone repayment for existing loans; $0 \%$ interest rates for new loans and some budget for unemployment benefits. The World Bank (2021) praised Vietnam as it showed resilience to the pandemic 2019-2020. Vietnam's successful containment of the COVID-19 outbreak with effective lockdown reported only 1,465 infected cases with 35 deaths by the end of 2020 (World Bank, 2021). The World Bank goes on to explain how it is resilient by showing the nation 2.9\% GDP growth during the pandemic 2019-2020. Even when it is the nation's lowest growth rate in the past decade, compared globally, Vietnam was one of the few countries in the world to have a positive growth during the pandemic.

Vietnam's lockdown closed its border to China, creating a shortage in materials for many industries, including the Footwear industry. The World Footwear Yearbook (2020) reported Vietnam footwear producers faced many challenges during the pandemic lack of materials, workers shortage due to covid prodecalled, and shift in consumer behaviors that lead to the cancellation of orders by many importers from the US and Europe. The U.S and Europe are two large markets that cover about $66 \%$ of Vietnam's footwear export (LEFASO, 2021). Which resulted in a drop in Vietnam footwear exports of 20\% (World Footwear, 2020). According to 
LEFASO (2021), Vietnam 2020 footwear export turnover was reduced by $8.6 \%$ from 2019 . The pandemic led to an estimated $52 \%$ of footwear manufacturers in Vietnam experiencing order cancellations and nearly 13\% had in-process orders canceled (World Footwear, 2020). The World Footwear Yearbook highlights that Vietnam has to import up to $60 \%$ of materials for footwear production, mainly from China, causing the shortage of the industry supply chain when COVID-19 outbreak in China. Canceling orders forcing companies to lay off staff to stay operated at minimum capacity. This creates a ripple effect of shortage in workers when many returns to their hometown and choose not to come back. Prior to this pandemic, McKenzie (2020) claims risk management principles often only applied to top-tier suppliers, leaving firms blindsided and vulnerable to shocks affecting their lower-tier suppliers. Domestic enterprises with limited capital, technical ability, and technology will have a harder time to recover and some even excite the market, disputed the supply chain. The shortage of materials or workers from lower-tier suppliers is critical to the overall supply-chain hierarchy, and disruptions at these levels can quickly cause disturbances throughout the chain (McKenzie, 2020). 


\section{Results/Discussion:}

The COVID-19 pandemic has been and still is raging around the world, isolating economies, distributed supply chains, and declining global demands. Depending on its export volume, Vietnam is seriously affected by the pandemic. Findings are based on secondary data, while results were confirmed or complemented by primary data in the form of large corporations' annual reports in the footwear industry. Then, I apply Porter's Diamond Model to the Vietnam footwear industry (factor conditions, demand conditions, strategy and rivalry, and related industries, Government, and change), identify the factors, and then find Vietnam opportunities for competitive advantage.

\section{Applying Porter's Diamond model:}

As explained in the theoretical section, Porter's Diamond Model is based on four interrelated factors: (1) factors conditions, (2) demand conditions, (3) related and supporting industries, and (4) firm strategy, structure, and rivalry. I am applying the model to the Vietnamese footwear industry to explore its competitiveness, and to answer my research question: What are the opportunities for Vietnam's Footwear industry to gain a competitive advantage over other nations after the 2019-2020 COVID-19 Pandemic?

\section{Factors conditions:}

Porter (1990) explains nations can achieve competitive advantage in a focused industry by creating and improving through advanced reinvestment factors such as knowledge, technology innovation, capital resources, and infrastructures. Vietnam's competitive advantage of low-cost labor in stimulating the country's economic growth in 2020. Porter (1990) argues unskilled labor cannot be the country's competitive advantage because he identifies it as a basic factor in factor conditions. Wolfram (2013) explains the result of low-cost laborers becoming a 
nation's competitive advantage is a nation's economic growth significantly, working conditions, and general quality of life for the entire country will improve. Vietnam's positive GDP growth in 2020 proved that the country has reliable capital resources, even during the pandemic. According to KPMG (2021), Vietnam's government infrastructure investment plans to expand and upgrade the existing transportation systems are focusing on Ho Chi Minh City as the key region. This is also the region where Nike has the majority of its footwear suppliers (Nike, Inc. 2021). Commitment to investing and building a stable infrastructure system to support the country's growth will play an essential role for the footwear industry to grow. It creates attractiveness for firms as they aim to reduce logistics costs, lead time, and risks in their supply chain.

The opportunities for Vietnam's footwear industry to grow in this factor are to focus on investments in automation footwear production, slowly replace low-wage workers, and increase capacity. Hoang \& Hong (2016) argue that low-cost workers' competitive advantage will not last long. Vietnamese shoe manufacturers must find other benefits for their manufacturing to achieve a sustainable competitive advantage. Hosting training and learning sessions will improve quality production; Vietnamese workers can learn quickly and train on knowledge to operate machines to innovate technologies. This process will prove beneficial and easy to implement due to the high literacy level of Vietnamese workers, the transition into creating high-skilled jobs, and knowledge transfer. Vietnam will need proper government support and intervention to accommodate the change of low into high labor (World Bank, 2021). The World Footwear Yearbook pointed out the challenge for the footwear industry in Vietnam is the need to integrate the technologies into its process (World Footwear, 2020). Information technology investments are relatively beneficial for young Vietnamese residents working for international companies to improve Vietnam's global integration. 


\section{Demand conditions:}

Suppose there is a high demand for the goods in the local market. Porter (1990) argues that it will create opportunities for local competitors to develop innovations to supply their goods to the local demand, leading to overall industry growth. Vietnam is prospering rapidly due to strong foreign capital inflow into Vietnam; the balance of export turnover has made an enormous difference, with the FDI sector taking the upper hand. The World Footwear Yearbook (2020) mentions Vietnam's export growth is increasingly dependent on FDI, while the domestic sector accounts for $23.7 \%$, the export share of the FDI sector is growing, reaching more than $76.3 \%$ in 2020. As the foreigners' own distribution networks increase in Vietnam, there will be a weakening in the network of domestic enterprises. Key competitors in the footwear industry like Nike and Adidas, were created, supported, and established by a high level of global distribution networks, having close to half of their footwear volume made from Vietnam, which in turn encourages Vietnam's footwear producers to join the global market (Nike, Inc., 2020; Adidas Group, 2019).

Opportunities for Vietnam's footwear industry to create sophisticated demand conditions are from local customers and support domestic enterprises. Domestic enterprises' performance depends on local customers. Vietnam will gain a competitive advantage in footwear industries if the local customers can give companies a clearer or earlier picture of emerging global buyer needs. Vietnam's economy grew compared to the rest of the world, even during the pandemic, leading to improvement in the quality of life for its citizens (KPMG, 2021). This in turn leads to higher demands from local customers to pressure domestic companies to innovate faster and achieve more sustainable competitive advantages than their foreign rivals. Vietnam's sustainable growth will be dependent on both export and domestic demand (Tsen, 2010). Suppose many 
suppliers within the country can produce goods or services with high standards of quality and quantity. In that case, the industry in that country will be more resilient than others (McKenzie, 2020). Domestic enterprises will need support in terms of investment capital to expand production, improve product quality, and increase competitiveness to support their growing local market.

\section{Related and supporting industry:}

The footwear industry is separated into four segments: sneakers, athletic footwear, leather footwear, and textile \& other footwear (DeSalva, 2020). Many components share the same suppliers with other sectors in Vietnam. Along with footwear, Vietnam's exports are also growing in different industries such as textiles, garments, and leather (KPMG, 2021). The Vietnam Leather and Footwear Association (LEFASO) and the Textile and Apparel Association (VITAS) help strengthen the relationships between these related industries (LEFASO, 2021). Collaboration with other related sectors, specializing in the production of fashion items, handbag, leather, textile, and apparel will be mutually beneficial, allowing all parties to utilize each other's resources, learn from each other, and potentially reach new customers.

Vietnam will need to focus on growing its upstream supply chain of the footwear industry. Enterprises in the industry need to work together to form production chains. Footwear enterprises should have a goal to collaborate with other businesses from similar sectors, diversifying the source of their materials. As $60 \%$ of all footwear materials are imported from China (World Footwear, 2020), it proved to be a risk in the supply chain during a global pandemic. Vietnam lacks information channels and support mechanisms. Using Nike's supply chain structure as an example (\#Figure7), having the Vietnam footwear industry focus on diversifying its tier 2 and 3 suppliers is an opportunity for the country to achieve a competitive 
advantage. Phan, Pham C.H, and Pham, L. mentions the domestic sector can supply less than 20 percent of these items' materials, due to"weak design capacity and weak material production and supply development" (2016, p. 79). During the pandemic of 2019-2020, Vietnamese footwear suppliers have been the most affected in its global supply chain, affecting not only foreign but also domestic suppliers. According to Handfield et al (2020), to mitigate the risk of disruptions, a network of repositories, fluid inventories, and analytic monitoring governed by the experts is required. Some organizations are better at reducing the severity and duration of disruptions to their products than their competitors. Many experts argued that this is because their supply chains are more resilient (Christopher and Peck, 2004; Sheffi and Rice, 2005). As the COVID-19 outbreak affected Vietnam's footwear industries this year, many enterprises have changed their product development strategy to increase the level of their resilience. Smaller enterprises need to seek guidance from associations such as LEFASO and VITAS, enhancing the connection, exchanging knowledge, innovating the industry, and supporting each other's growth.

\section{Firm strategy, structure, and rivalry:}

According to Porter (1990), the firm's strategy, structure, and rivalry factor is the most critical competitive advantage. Footwear competitiveness is determined by the level of enterprise rivalry in the industry within the nation. Each firm has its own set of structures and unique strategies to achieve its competitiveness. It is essential to know that the footwear industry competition is in sales numbers and by sourcing materials, innovating technology, design, and quality. There are currently over 2000 footwear manufacturers in Vietnam (LEFASO, 2021); a large number of these facilities support key players in the footwear supply chain, such as Nike and Adidas. Alongside their strong brand awareness achieved by clever marketing campaigns, 
Nike and Adidas's strategy of increasing production in Vietnam has contributed to their competitive advantage in the industry.

Opportunities for the Vietnam footwear industry in firm strategy, structure, and rivalry factor are increasing demand for footwear in Vietnam from smaller players in the industry. It will lead to a higher level of rivalry between Vietnam domestic enterprises to compete for their right to integrate with the global supply chain. Vietnamese firms can promote and gain their market presence by focusing on quality standards, ensuring the rate of locally-made products, and committing social responsibilities. The World Footwear Yearbook claims by applying new technologies such as green production, safety consumption, and environmental protection, local enterprises will innovate and promote the country to gain a competitive advantage in the industry (2020).

\section{Role of Government:}

Porter (1990) noted the role of the government to raise their aspirations and move to higher levels of competitive performance in the industry to create national economic growth. According to the Vietnam Outlook section, the Vietnamese Government supports the footwear industry to achieve competitiveness by investing and improving the nation's infrastructure, creating skilled workers, eliminating tariffs, and making regulations that benefit FDI. Free trade agreements (FTAs) will assist Vietnam in moving up the value chain in several sectors, including footwear, and transition into supporting high-skilled jobs and knowledge transfer. Vietnam already has FTAs with several Asian countries, giving access to the region with the most footwear consumption. Vietnam is benefiting from low and free duty from various FTAs, driving significantly increased FDI, and making the nation the leading trade partner for many countries. 
The Vietnamese Government promotes the industry by welcoming and placing priorities for foreign investors in the footwear sector.

Opportunities for Vietnam's Government to support the footwear industry are to continue to participate in more FTAs and focus on creating a fair market for the domestic producer. Nike's primary market is in North America. Suppose Vietnam starts FTAs with the United States. The nation's footwear exports will come closer to achieving a globally trade free. If Vietnam to achieve having FTAs with all major footwear consumption market regions, both EU and NA (\#Figure 3). The industry should aim for rapid, sustainable development and better use of trade deals to expand exports. Investors are more willing to risk their investment money in Vietnam because of the guarantees to the free trade market. More importantly, for Vietnam footwear to recover after the pandemic 2019-2020, local producers need support from their government and more capital investment. As Vietnam focuses on its FDI, the Government must also support a fair market for domestic enterprises. Governments promoting domestic enterprises will help encourage investments, increasing the competition and the local market presence. According to Porter (1990), "strict Government regulations can promote competitive advantage by stimulating and upgrading domestic demand" (p. 27). With government support, footwear enterprises will be more likely to improve quality, upgrade technology, and provide features that match consumers and social demands.

\section{Chance:}

According to Porter (1990), chance factors happen over a short period and could have a long-lasting ripple effect on the industry. Pre-pandemic, the footwear industry poised for continued growth (DeSalva, 2020). The pandemic 2019-2020 recession will reshape the footwear industry. Customer behavior shifts and supply chain disruptions have made Vietnam footwear 
export fail to achieve its target in 2020 as consumers pull back spending on discretionary items, such as footwear (LEFASO, 2021; DeSalva, 2020). Footwear purchases declined, leading to many companies having to cancel or reduce their orders significantly to not create a surplus. As Vietnam has controlled the impact of the pandemic well, Vietnamese footwear companies still have challenges in materials and worker shortage.

After the pandemic, opportunities for the Vietnam footwear industry are to improve its materials supply chain and production capabilities. With more than half of the footwear industry raw materials imported from China, there have been several challenges for Vietnam producers when the global supply chain is disputed (World Footwear, 2020). With many FTAs (KPMG, 2021), Vietnam should diversify its supply chain in other countries to build the nation's resilience. Vietnamese enterprises need to take advantage of the no/low-order period to organize training courses to improve workers' skills (World Footwear, 2020). This will be a perfect time to test new ways to integrate new technologies and increase labor productivity with low risk on productions. 


\section{Conclusion}

China remains the undisputed leader in footwear manufacturing. The Vietnamese footwear industry will have a chance to increase its share in the global supply chain as China's footwear market share in the world has decreased due to the impact of virus, increased cost, and trade wars. It is essential to discover Vietnam's opportunities to take advantage of the pandemic situation to create a competitive advantage for the Vietnamese footwear industry. We started the paper by explaining essential concepts for a better understanding of the paper. Then we explored Michael Porter's Diamond Model. Following was an explanation of the methodology and strategies utilized to answer the research question and analyze our data. The longest part was empirical data: the primary and secondary data used in the next part to discuss results with a theoretical model. And the last section, the conclusions to report the finding of the study.

To conclude our research question: What are the opportunities for Vietnam's Footwear industry to achieve a competitive advantage over other nations after the 2019-2020 COVID-19 Pandemic? the paper discovers opportunities within each factor in Michael Porter's Diamond Model. Consequently, the pandemic has demonstrated how both suppliers and firms can innovate during a crisis. During the pandemic crisis, we have learned that organizations worldwide that were involved in manufacturing have been significantly affected. To overcome difficulties and gain access to resources that contribute to their competitive advantage, Vietnam's footwear industry investment opportunities are in automation technologies, sophisticated domestic buyers, domestic enterprises, diversified relationships with supporting industries, commitment to social responsibilities, and workers' skills. The pandemic has demonstrated how both suppliers and firms should consistently innovate to minimize disruptions during a crisis. 


\section{Reference}

Abdulkadir, A., Afriana, Wendra., \& Azis, H. A. (2020). Footwear Export Competitiveness of Indonesia-Vietnam. Signifikan: Jurnal Ilmu Ekonomi, 9(2), 269-284. doi: http://doi.org/10.15408/sjie.v9i2.15404.

Adidas Group(2010) Annual report 2010. https://www.annualreports.com/HostedData/AnnualReportArchive/a/OTC ADDDF 201 $\underline{0 . p d f}$

Adidas Group (2011) Annual report 2011. https://www.adidas-group.com/media/filer_public/2b/68/2b6857a3-8b2e-4a78-bbee-1d60 151b6fbf/ag_2011_en.pdf

Adidas Group (2012) Annual report 2012. https://www.adidas-group.com/media/filer public/2013/07/31/gb 2012 en.pdf

Adidas Group (2013) Annual report 2013. https:/www.adidas-group.com/media/filer public/2014/03/05/adidas-group gb 2013 en .pdf

Adidas Group (2014) Annual report 2014. https://www.adidas-group.com/media/filer_public/2b/2f/2b2fd619-5444-4ee8-9c07-baa8 $\underline{78 \mathrm{~d} 658 \mathrm{c} 4 / 2014 \mathrm{gb} \text { en.pdf }}$

Adidas Group (2015) Annual report 2015. https://www.adidas-group.com/media/filer_public/e9/73/e973acf3-f889-43e5-b3c0-bc870 d53b964/2015 gb en.pdf

Adidas Group (2016) Annual report 2016. https://www.adidas-group.com/media/filer_public/a3/fb/a3fb7068-c556-4a24-8eea-cc009 51a1061/2016 eng_gb.pdf

Adidas Group (2017) Annual report 2017. https://www.adidas-group.com/media/filer_public/6a/69/6a690baa-8430-42c5-841d-d922 2a150aff/annual report gb-2017 en secured.pdf

Adidas Group (2018) Annual report 2018. https://www.adidas-group.com/media/filer_public/e9/ba/e9bad34f-ca11-44f6-977f-364d0 650feaf/annual_report_gb-2018-en_secured.pdf

Adidas Group (2019) Annual report 2019. 
https://www.adidas-group.com/media/filer_public/a8/5c/a85c9b8e-865b-4237-8def-8574 be243577/annual report gb-2019 en.pdf

Altomonte, Carlo \& Aquilante, Tommaso \& Ottaviano, Gianmarco. (2012). The triggers of competitiveness: The EFIGE cross-country report.

ASIC. (2010) Annual report 2010. https://asic.gov.au/media/1817681/asic annualreport-2009-10.pdf

ASIC. (2011) Annual report 2011. https://assets.asics.com/page types/1914/files/2011 original.pdf?1387417739

ASIC. (2012) Annual report 2012. https://asic.gov.au/media/1311019/ASIC-Annual-Report-2012-13-complete.pdf

ASIC. (2013) Annual report 2013. https://download.asic.gov.au/media/2227467/asic-annual-report-2013-14.pdf

ASIC. (2014) Annual report 2014. https://download.asic.gov.au/media/3437945/asic-annual-report-2014-15-full.pdf

ASIC. (2015) Annual report 2015. https://download.asic.gov.au/media/4058626/asic-annual-report-2015-2016-complete.pdf

ASIC. (2016) Annual report 2016. https://download.asic.gov.au/media/4527819/annual-report-2016-17-published-26-octobe $\underline{\text { r-2017-full.pdf }}$

ASIC. (2017) Annual report 2017. https://download.asic.gov.au/media/4922570/annual-report-2017-18-published-31-octobe r-2018-full.pdf

ASIC. (2018) Annual report 2018. https://download.asic.gov.au/media/5314396/asic-annual-report-2018-19-full.pdf

ASIC. (2019) Annual report 2019. https://assets.asics.com/page types/4381/files/ASICS\%20Annual\%20Report\%202019 or iginal original.pdf?1590396083

Bryman A. \& Bell, E. (2015) "Business Research Methods" 4th edition, Oxford University Press, p. 27 
Carr, L. T. (1994). The strengths and weaknesses of quantitative and qualitative research: what method for nursing?. Journal of advanced nursing, 20(4), 716-721.

Christopher, M. and Peck, H. (2004), "Building the resilient supply chain”, International Journal of Logistics Management, Vol. 15 No. 2, pp. 1-13.

DeSalva, A. (2020, May). Men's \& Women's Footwear: Incl Impact of COVID-19 - US - May 2020. Retrieved November 03, 2020, from https://reports.mintel.com/display/987010/

Donnellan, M. B., \& Lucas, R. E. (2013). Secondary data analysis. In T. D. Little (Ed.), Oxford library of psychology. The Oxford handbook of quantitative methods: Statistical analysis (p. 665-667). Oxford University Press.

Footwear report 2020 - Vietnam. (2020) Statista Consumer Market Outlook Retrieved May 20, 2021, from https://www-statista-com.proxy.lib.pdx.edu/outlook/cmo/footwear/vietnam

Goddard, W.\& Melville, S., (2004). Research Methodology: An Introduction. (2nd ed.) Oxford: Blackwell Publishing.

Handfield., Robert, Finkenstadt, Daniel Joseph, Schneller, Eugene S, Godfrey, A. Blanton, \& Guinto, Peter. (2020). A Commons for a Supply Chain in the Post-COVID-19 Era: The Case for a Reformed Strategic National Stockpile. The Milbank Quarterly, 98(4), 1058-1090. https://doi.org/10.1111/1468-0009.12485

Haradhan, Mohajan. (2018) Qualitative Research Methodology in Social Sciences and Related Subjects. Journal of Economic Development, Environment and People, Vol-7, Issue 01, 2018, pp. 23-48

Hong, J., Chu, Z., \& Wang, Q. (2011). Transport infrastructure and regional economic growth:

Evidence from china. Transportation, 38(5), 737-752.

doi:http://dx.doi.org.proxy.lib.pdx.edu/10.1007/s11116-011-9349-6

International Labour Organization. (2020). ILO Monitor: COVID-19 and the World

of Work. Second Edition. Updated Estimates and Analysis [press release].

Geneva: International Labour Organization. 
https://www.ilo.org/wcmsp5/groups/public/---dgreports/---dcomm/documents/brie fingnote/wcms 740877.pdf

Katelynn, Harris. and Michael, D. McCall. ( December 2019) "The relative weakness in earnings of production workers in manufacturing, 1990-2018," Monthly Labor Review, U.S. Bureau of Labor Statistics, , https://doi.org/10.21916/mlr.2019.27.

KPMG (2021). Investing in Vietnam 2021 and beyond Redrawing the horizon. Retrieved from https://assets.kpmg/content/dam/kpmg/vn/pdf/publication/2021/Investing-in-Vietnam-20 21.pdf

Laudon, K. C., Jane P. Laudon, J. P. (2018). Management information systems: managing the digital firm. Fifteenth Edition. Pearson.

Leading Footwear Exporting Nations, 2018. (2021). In V. L. Burton, III \& R. S. Lazich (Eds.), Market Share Reporter (31st ed.). Farmington Hills, MI: Gale. Retrieved from https://bi-gale-com.proxy.lib.pdx.edu/global/article/GALE\%7CI2502070553/65f42fb8d3 $\underline{0 \mathrm{ad} 1 \mathrm{db} 722 \mathrm{~d} 7 \mathrm{f} 9 \mathrm{ac} 3 \mathrm{ee} 630 \mathrm{e} ? \mathrm{u}=\mathrm{s} 1185784}$

Liz, Yeomans. (2017) Qualitative methods in business research, Action Learning: Research and Practice, 14:3, 298-301.

Mabert, Vincent \& Venkataramanan, Munirpallam. (2007). Special Research Focus on Supply Chain Linkages: Challenges for Design and Management in the 21st Century*.

McKinsey Company. (2019, July 1). China and the World: Inside the dynamics of a changing relationship. Retrieved April 21, 2021, from https://www.mckinsey.com/featured-insights/china/china-and-the-world-inside-the-dyna mics-of-a-changing-relationship

McKenzie, B. (2020, April). Beyond COVID-19: Supply Chain Resilience Holds Key to Recovery. Retrieved April 18, 2021, from https://www.bakermckenzie.com/-/media/files/insight/publications/2020/04/covid19-glob al-economy.pdf 
Naoui, F. (2014), Customer service in supply chain management: a case study. J Enterp Inf Manag 27(6):786-801

Nguyen,Van Q., Cao, D. A., \& Nghiem, S. H. (2021). Spread of COVID-19 and policy responses in Vietnam: An overview. International journal of infectious diseases : IJID : official publication of the International Society for Infectious Diseases, 103, 157-161. https://doi.org/10.1016/j.ijid.2020.11.154

Nike, Inc. (2020) Form 10-K 2020. https://s1.q4cdn.com/806093406/files/doc_financials/2020/ar/NKE-FY20-10K.pdf

Nike, Inc. (2019) Form 10-K 2019. https://s1.q4cdn.com/806093406/files/doc_financials/2019/annual/nike-2019-form-10K.p df

Nike, Inc. (2018) Form 10-K 2018.

https://s1.q4cdn.com/806093406/files/doc_financials/2018/ar/docs/nike-2018-form-10K. pdf

Nike, Inc. (2017) Form 10-K 2017. https://s1.q4cdn.com/806093406/files/doc_financials/2017/ar/docs/nike-2017-form-10K. pdf

Nike, Inc. (2016) Form 10-K 2016.

https://s1.q4cdn.com/806093406/files/doc financials/2016/ar/docs/nike-2016-form-10K. pdf

Nike, Inc. (2015) Form 10-K 2015.

https://www.sec.gov/Archives/edgar/data/320187/000032018715000113/nke-5312015x1 0k.htm

Nike, Inc. (2014) Form 10-K 2014. 
https://www.sec.gov/Archives/edgar/data/320187/000032018714000097/nke-5312014x1 0k.htm

Nike, Inc. (2013) Form 10-K 2013.

https://www.sec.gov/Archives/edgar/data/320187/000032018713000092/nke-5312013x1 0k.htm

Nike, Inc. (2012) Form 10-K 2012.

https://www.sec.gov/Archives/edgar/data/320187/000119312512312306/d341264d10k.ht $\mathrm{m}$

Nike, Inc. (2011) Form 10-K 2011.

https://www.sec.gov/Archives/edgar/data/320187/000119312511194791/d10k.htm

Nike, Inc. (2010) Form 10-K 2010.

https://www.sec.gov/Archives/edgar/data/320187/000119312510161874/d10k.htm

Nike, Inc. (2021) Nike manufacturing map. Retrieved from

http://manufacturingmap.nikeinc.com/

The Organisation for Economic Co-operation and Development. (OECD) (2009), “Aggregate national accounts: gross domestic product", OECD National Accounts Statistics (database), http://dx.doi.org/10.1787/data-00001-en

Ojeda-Gomez, J., Simpson, M., Lenny Koh, S.C. and Padmore, J. (2007), "Achieving competitive advantage in the Mexican footwear industry", Benchmarking: An International Journal, Vol. 14 No. 3, pp. 289-305. https://data.oecd.org/gdp/gross-domestic-product-gdp.htm

Parasuraman, A. (1991). Marketing Research. (2nd Ed). Addison-Wesley.

Patton, M. Q. (1987). How to use qualitative methods in evaluation (No. 4). Sage.

Phan, X. T. T., Pham, C. H., \& Pham, L. (2016). The Competitive Advantages of Vietnam 
Footwear Industry: An Analysis. International Journal of Financial Research. https://doi.org/10.5430/ijfr.v7n3p65

Porter, M. E. (1990). The Competitive Advantage of Nations. New York: Free Press.

PUMA(2010) Annual report 2010. https://about.puma.com/en/investor-relations/financial-reports

PUMA(2011) Annual report 2011. https://about.puma.com/en/investor-relations/financial-reports

PUMA(2012) Annual report 2012. https://about.puma.com/en/investor-relations/financial-reports

PUMA(2013) Annual report 2013. https://about.puma.com/en/investor-relations/financial-reports

PUMA(2014) Annual report 2014. https://about.puma.com/en/investor-relations/financial-reports

PUMA(2015) Annual report 2015. https://about.puma.com/en/investor-relations/financial-reports

PUMA(2016) Annual report 2016. https://about.puma.com/en/investor-relations/financial-reports

PUMA(2017) Annual report 2017. https://about.puma.com/en/investor-relations/financial-reports

PUMA(2018) Annual report 2018. https://about.puma.com/en/investor-relations/financial-reports

PUMA(2019) Annual report 2019. https://about.puma.com/en/investor-relations/financial-reports

PUMA(2020) Annual report 2020. https://about.puma.com/en/investor-relations/financial-reports

Rothaermel, F. T. (2009). Strategic management. In Strategic management (4th ed., pp. 4-7).

United States: McGraw-Hill/Irwin.

Scholten, K., Stevenson, M. and van Donk, D.P. (2020), "Dealing with the unpredictable: supply chain resilience", International Journal of Operations \& Production Management, Vol. 40 No. 1, pp. 1-10. https://doi-org.proxy.lib.pdx.edu/10.1108/IJOPM-01-2020-789

Shahbandeh, M. (2021, February 19). Topic: Global footwear market- Statistics \& Facts. Retrieved April 20, 2021, from https://www.statista.com/topics/4571/global-footwear-market/\#dossierSummary chapte $\underline{\mathrm{r} 1}$

Sheffi, Y. (2005), The Resilient Enterprise: Overcoming Vulnerability for Competitive 
Advantage, MIT Press, Cambridge, MA

Smit, A. (2010). The competitive advantage of nations: is Porter's Diamond Framework a new theory that explains the international competitiveness of countries? Southern African Business Review, 14, 105-130.

SourceToday. (April 17, 2017). Manufacturing labor costs per hour for China, Vietnam, Mexico from 2016 to 2020 (in U.S. dollars) [Graph]. In Statista. Retrieved May 18, 2021, from https://www-statista-com.proxy.lib.pdx.edu/statistics/744071/manufacturing-labor-costsper-hour-china-vietnam-mexico/

Tsen, W.H. (2010), Exports, Domestic Demand, and Economic Growth in China: Granger Causality Analysis. Review of Development Economics, 14: 625-639. https://doi.org/10.1111/j.1467-9361.2010.00578.x

Vietnam's Leather, Footwear and Handbags Association. -(LEFASO)- (2021) NGÀNH GIÀY DA VIẸT NAM Retrieved May 10, 2021 http://www.lefaso.org.vn/chi-tiet-tin-tuc/26440/ban-tin-xuat-nhap-khau-nganh-da-giay-th ang-4-2021

Wolfram, Jordon A. (2013) "Allowing for Low-Cost Labor in Underdeveloped and Developing Countries as a Method for Initiating Economic Industrialization" . Selected Honors Theses. Paper 29.

World Bank. (2019, December 17). Vietnam's economy expanded by 6.8 percent in 2019 but reforms are needed to unleash the potential of capital markets. Retrieved April 28, 2021, from

https://www.worldbank.org/en/news/press-release/2019/12/17/vietnams-economy-expand ed-by-68-percent-in-2019-but-reforms-are-needed-to-unleash-the-potential-of-capital-ma $\underline{\text { rkets.print }}$

World Bank. (2021).The World Bank In Vietnam. Retrieved April 28, 2021, from https://www.worldbank.org/en/country/vietnam/overview

World Economic Outlook. (January, 2020) World Economic Outlook reports January 2020 
Retrieved May 10, 2021

https://www.imf.org/en/Publications/WEO/Issues/2020/01/20/weo-update-january2020

World Footwear. (2019). Vietnam is already taking advantage of the US-China trade war Received from

https://www.worldfootwear.com/news/vietnam-is-already-taking-advantage-of-the-us-chi na-trade-war/4059.html

World Footwear. (2020). 2020 edition of The World Footwear Yearbook. Received from https://www.worldfootwear.com/news/find-out-about-where-footwear-exports-are-concen trated/5547.html

WTO. (2021). World trade organization-Vietnam. Retrieved April 29, 2021, from https://www.wto.org/english/thewto_e/countries_e/vietnam e.htm 